\title{
Article \\ Synthesis and Antimicrobial, Anticancer and Anti-Oxidant Activities of Novel 2,3-Dihydropyrido[2,3-d]pyrimidine-4-one and Pyrrolo[2,1-b][1,3]benzothiazole Derivatives via Microwave-Assisted Synthesis
}

\author{
Aamal A. Al-Mutairi ${ }^{1}$, Hend N. Hafez ${ }^{2, *}{ }^{\mathbb{D}}$, Abdel-Rhaman B. A. El-Gazzar ${ }^{2}$ and Marwa Y. A. Mohamed ${ }^{3}$ \\ 1 Chemistry Department, Faculty of Science, Saudi Arabia; Imam Mohammad Ibn Saud Islamic \\ University (IMSIU), P.O. Box 90950, Riyadh 11623, Saudi Arabia; aamutairi@imamu.edu.sa \\ 2 Heterocyclic \& Nucleosides Unit, Photochemistry Department, National Research Centre, Dokki, \\ Giza 12622, Egypt; profelgazzar@yahoo.com \\ 3 Biology Department, Faculty of Science, Saudi Arabia; Imam Mohammad Ibn Saud Islamic \\ University (IMSIU), P.O. Box 90950, Riyadh 11623, Saudi Arabia; Yousry_marwa@yahoo.com \\ * Correspondence: dr.hendhafez@yahoo.com
}

check for updates

Citation: Al-Mutairi, A.A.; Hafez, H.N.; El-Gazzar, A.-R.B.A.; Mohamed, M.Y.A. Synthesis and Antimicrobial, Anticancer and Anti-Oxidant Activities of Novel 2,3-Dihydropyrido[2,3-d]pyrimidine4-one and Pyrrolo[2,1-b][1,3] benzothiazole Derivatives via Microwave-Assisted Synthesis. Molecules 2022, 27, 1246. https:// doi.org/10.3390/molecules27041246 Academic Editors: Krešimir Pavelić, Sandra Kraljević Pavelić and Rafik Karaman

Received: 9 January 2022

Accepted: 10 February 2022

Published: 12 February 2022

Publisher's Note: MDPI stays neutra with regard to jurisdictional claims in published maps and institutional affiliations.

Copyright: (C) 2022 by the authors. Licensee MDPI, Basel, Switzerland. This article is an open access article distributed under the terms and conditions of the Creative Commons Attribution (CC BY) license (https:// creativecommons.org/licenses/by/ $4.0 /)$

\begin{abstract}
In our attempt towards the synthesis and development of effective antimicrobial, anticancer and antioxidant agents, a novel series of 2,3-dihydropyrido[2,3-d]pyrimidin-4-one 7a-e and pyrrolo[2,1-b][1,3]benzothiazoles 9a-e were synthesized. The synthesis of 2-(1,3-benzo thiazol-2-yl)3-(aryl)prop-2-enenitrile (5a-e) as the key intermediate was accomplished by a microwave efficient method. Via a new variety oriented synthetic microwave pathway, these highly functionalized building blocks allowed access to numerous fused heteroaromatic such as 7-amino-6-(1,3-benzo thiazol-2-yl)-5-(aryl)-2-thioxo-2,3dihydropyrido [2,3-d]pyrimidin-4(1H)-one 7a-e and 1-amino-2(aryl)pyrrolo[2,1-b][1,3] benzothiazole-3-carbonitrile derivatives 9a-e in order to study their antimicrobial and anticancer activity. The present investigation offers effective and rapid new procedures for the synthesis of the newly polycondensed heterocyclic ring systems. All the newly synthesized compounds were evaluated for antimicrobial, anticancer and antioxidant activity. Compounds 7a,d, and $\mathbf{9 a}, \mathbf{d}$ showed higher antimicrobial activity than cefotaxime and fluconazole while the remaining compounds exhibited good to moderate activity against bacteria and fungi. An anticancer evaluation of the newly synthesized compounds against the three tumor cell lines (lung cell NCI-H460, liver cancer HepG2 and colon cancer HCT-116) exhibited that compounds $7 \mathbf{a}, \mathbf{d}$, and $\mathbf{9 a}$,d have higher cytotoxicity against the three human cell lines compared to doxorubicin as a reference drug. These compounds also exhibited higher antioxidant activity and a great ability to protect DNA from damage induced by bleomycin.
\end{abstract}

Keywords: pyrido[2,3-d]pyrimidine; pyrrolo[2,1-b][1,3]benzothiazole; arylidenes; microwave; antimicrobial; anticancer; antioxidant activity

\section{Introduction}

Cancer is one of the most serious health problems globally and is one of the main causes of increases in the death rate. Accordingly, there is an urgent requirement to make more effort to modify drugs and motivate the synthesis of new chemical bioactive compounds that establish improvement through current therapies. Pyrido[2,3-d]pyrimidine is one of the most privileged heterocyclic frameworks in several efficacious pharmacological compounds. Pyrido[2,3-d]pyrimidine ring systems have assorted biological and pharmacological activities such as being analgesic, anti-inflammatory [1-3], antitubercular [4], antimicrobial [5-7], a threonine tyrosine kinase (TTK) inhibitor [8], an adenosine kinase inhibitor [9], antiviral [10], antioxidant [11-14], a dihydrofolate reductase inhibitor [15,16], and an efficient glucosidase inhibitor $[17,18]$. Moreover, the 1,3-benzothiazole nucleus is a 
highly significant scaffold in the drug design, due to important pharmacological and medicinal activities, such as being antiviral [19], antituberculosis [20], an identifier of selective CB2 receptor ligands [21], antitumor [22-24], antimicrobial [25-27], anticonvulsant [28], a schistosome BCL-2 inhibitor [29], antidiabetic [30], antioxidant [31], an anti-Alzheimer drug [32] and a urease inhibitor [33] among the heterocyclic compounds containing a pyrimidine and benzothiazole nucleus that exhibits biological activity [34-36] (Figure 1).<smiles>CCOc1ccc2nc(N3CN(c4ccccc4)c4ncccc4C3=O)sc2c1</smiles><smiles>Nc1nc2c(c(=O)[nH]1)C(c1ccc(F)cc1)C(c1ccccc1)=C(c1ccccc1)N2</smiles><smiles>Fc1ccc2c(c1)sc1nc(-c3ccccc3)c(CN3CCCC3)n12</smiles>

Figure 1. Chemical structure of biologically active compounds.

Accordingly, with all of the previous observations of the biological importance and in continuation of our program in the synthesis of pyrido[2,3-d]pyrimidine [37], this study aims to design and develop highly selective and efficacious antimicrobial and anticancer agents of a novel series of pyrido[2,3-d]pyrimidine derivatives bearing different heterocyclic and aryl moieties such as benzothiazole, thiophene, furan, piperonal, naphthalene, and fluorophenyl as a side chain and various aryl derivatives by the microwave irradiation technique.

We have also reported here the synthesis of pyrrolo[2,1-b][1,3]benzothiazole bearing aryl and heteroaryl derivatives under microwave irradiation in the hope of obtaining novel antimicrobial and anticancer agents with excellent yield. Nowadays, the microwave irradiation method is a steady and attractive method for the synthesis of polycondensed heterocyclic compounds due to rapid, simple, and high yields [38,39].

\section{Results}

\subsection{Chemistry}

The synthetic strategy of 2-(1,3-benzothiazol-2-yl)-3-(aryl)prop-2-enenitrile derivatives 5a-e includes two steps outlined in Scheme 1. Synthesis of 2-cyano -methyl-1,3benzothiazol 3 by a newly highly efficient method with high yield $(92 \%)$ under microwave irradiation at $40{ }^{\circ} \mathrm{C}$ for $10 \mathrm{~min}$ by the reaction of 2-amino thiophenol 1 with malononitrile 2 in ethanol $(10 \mathrm{~mL})$ and acetic acid as a catalyst is compared to the old method with low yield and long reaction time [40]. Knoevenagel condensation of active methylene 3 with appropriate aromatic aldehyde using absolute ethanol in the presence of a catalytic amount of triethylamine under MWI at $60^{\circ} \mathrm{C}$ afforded compounds $5 \mathbf{a}-\mathbf{e}$ as shown in Table 1 . The progress of the reaction was followed by TLC (petroleum ether (80-90): ethylacetate, ratio: 3:1). The structure of the newly synthesized compounds was established by spectral data and elemental analysis. 


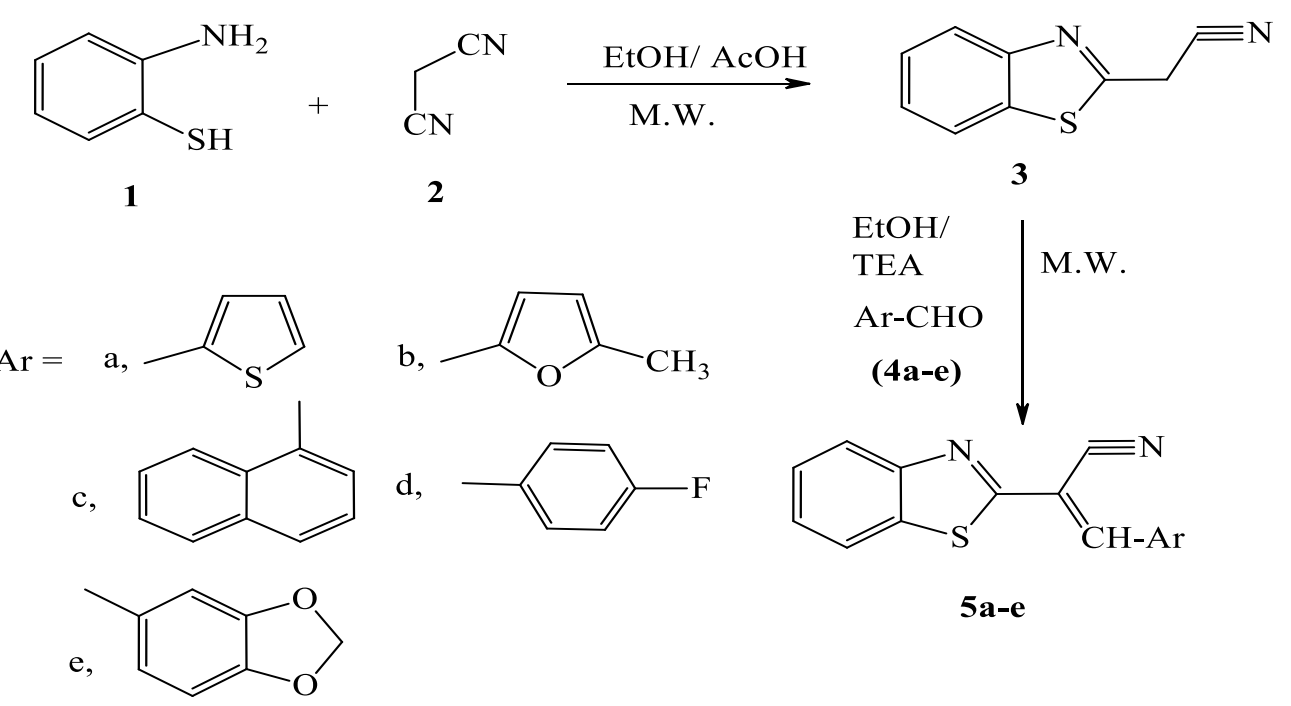

Scheme 1. Synthesis of 2-(1,3-benzothiazol-2-yl)-3-(aryl)prop-2-enenitrile derivatives (5a-e).

Table 1. Microwave-assisted reaction of 2-cyanomethyl-1,3-benzothiazol and aldehydes.

\begin{tabular}{|c|c|c|c|c|}
\hline Entry & Substrate & Product & Time & Yield (\%) \\
\hline 1 & & $5 a$ & $6 \mathrm{~min}$ & 87 \\
\hline 2 & & $5 b$ & $6 \mathrm{~min}$ & 84 \\
\hline 3 & & $5 c$ & $8 \mathrm{~min}$ & 90 \\
\hline 4 & & $5 d$ & $4 \mathrm{~min}$ & 96 \\
\hline 5 & & $5 e$ & $8 \mathrm{~min}$ & 92 \\
\hline
\end{tabular}

Under microwave irradiation conditions, the treatment of the reactive intermediates 5a-e with 6-aminothiouracil 6 using triethylamine as a catalyst in absolute ethanol at $100{ }^{\circ} \mathrm{C}$ generated the desired product 7a-e with (49-53\%) yield within $45 \mathrm{~min}$. Interestingly, the use of dimethylformamide instead of ethanol as a solvent without a catalyst at $150{ }^{\circ} \mathrm{C}$ afforded the most satisfactory results of the corresponding 7-amino-(1,3-benzothiazol-2-yl)2-thioxo-2,3-dihydropyrido[2,3-d]pyrimidin-4-one derivatives 7a-e in high yield within $25 \mathrm{~min}$ as shown in (Table 2).

Nevertheless, heating under reflux of compounds 5a-e with 6 whether in DMF or ethanol $\backslash$ TEA for a long time afforded (7a-e) as shown in Scheme 2. 
Table 2. Reaction conditions: reaction of 2-(1,3-benzothiazol-2-yl)-3-(aryl)prop-2-enenitrile derivatives (5a-e) and 6-aminothiouracil 6 was heated or irradiated by microwave.

\begin{tabular}{|c|c|c|c|c|c|c|c|}
\hline \multirow{2}{*}{ Entry } & \multirow{2}{*}{ Substrate } & \multirow{2}{*}{ Solvent } & \multirow{2}{*}{\multicolumn{2}{|c|}{$\frac{\text { Method/Time }}{\mathcal{C}_{\text {Conventional, h MWI, }}^{\text {min }}}$}} & \multirow{2}{*}{\multicolumn{2}{|c|}{$\begin{array}{c}\text { Method/Yield \% } \\
\begin{array}{c}\text { Conventional, h MWI, } \\
\text { min }\end{array}\end{array}$}} & \multirow{2}{*}{ Product } \\
\hline & & & & & & & \\
\hline \multirow[t]{2}{*}{1} & & DMF & 28 & 25 & 62 & 89 & $7 a$ \\
\hline & & EtOH/TEA & 36 & 45 & 48 & 53 & \\
\hline \multirow[t]{2}{*}{2} & & DMF & 27 & 25 & 60 & 85 & $7 \mathrm{~b}$ \\
\hline & & EtOH/TEA & 36 & 45 & 43 & 51 & \\
\hline \multirow[t]{2}{*}{3} & & DMF & 28 & 25 & 63 & 88 & $7 \mathrm{c}$ \\
\hline & & EtOH/TEA & 40 & 45 & 41 & 49 & \\
\hline \multirow[t]{2}{*}{4} & & DMF & 25 & 25 & 65 & 92 & $7 d$ \\
\hline & & EtOH/TEA & 35 & 45 & 48 & 53 & \\
\hline \multirow[t]{2}{*}{5} & & DMF & 30 & 25 & 60 & 84 & $7 e$ \\
\hline & & $\mathrm{EtOH} / \mathrm{TEA}$ & 42 & 45 & 39 & 50 & \\
\hline
\end{tabular}

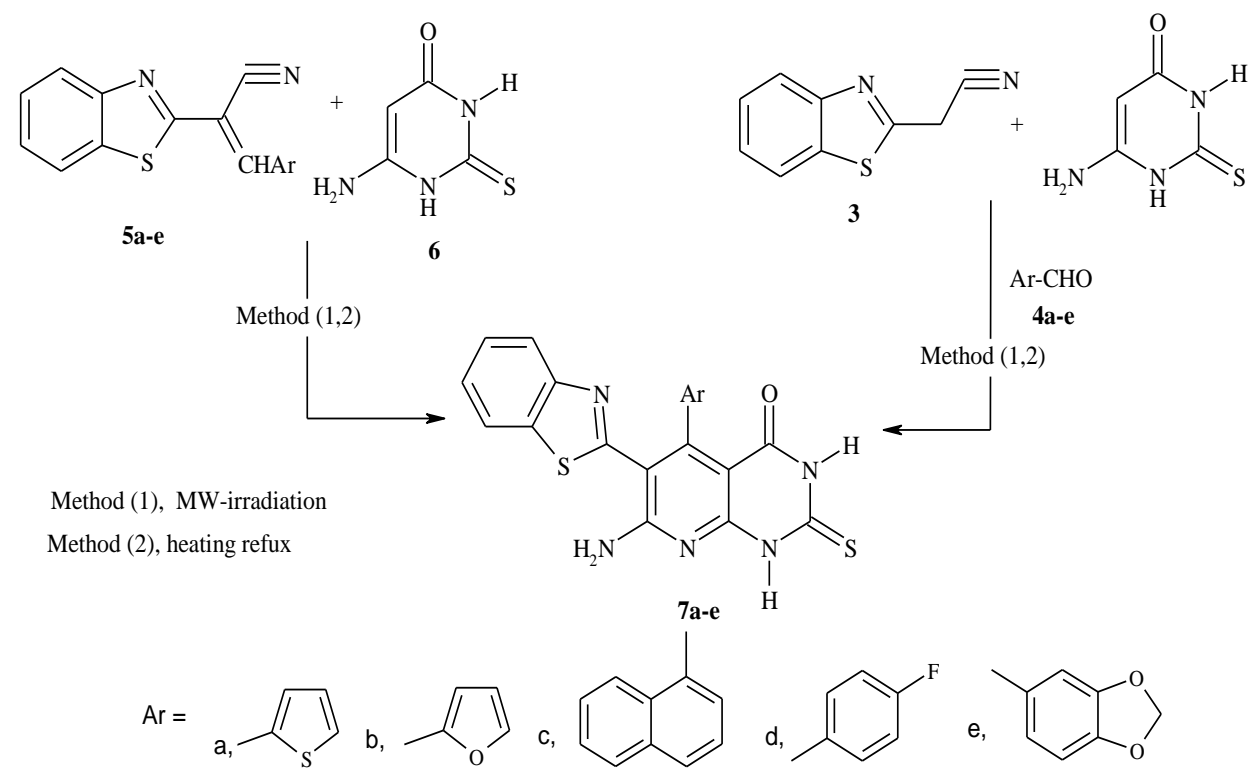

Scheme 2. Synthesis of 5-amino-6-(1,3-benzothiazol-2-yl)-7-(substituted phenyl)-2-thioxo- 2,3dihydro-pyrido[2,3-d]pyrimidin-4(1H)-one derivatives $7 \mathbf{a}-\mathbf{e}$. 
A possible mechanism for the formation of 2,3-dihydropyrido[2,3-d]pyrimidin-4-one derivatives (7a-e) was proposed in Scheme 3.
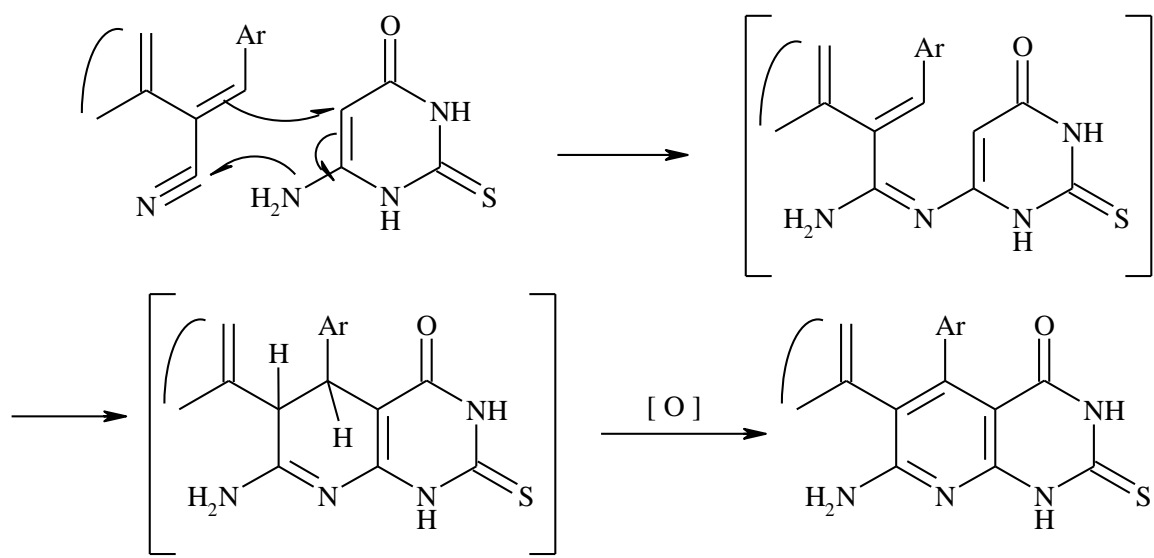

Scheme 3. Mechanism for formation of 2,3-dihydropyrido[2,3-d]pyrimidin-4-one derivatives (7a-e).

In this research, we have also studied the possibility of the multicomponent reaction of 2-cyanomethyl-1,3-benzothiazol 3, 6-aminothiouracil 6, and appropriate aldehydes 4a-e under microwave irradiation conditions at $150^{\circ} \mathrm{C}$ and TLC control. Pyrido[2,3-d]pyrimidine derivatives $\mathbf{7 a - e}$ were accumulated, the reaction condition has been established in Table 3 . On the other hand, the same reaction was carried out by conventional heating under reflux in DMF as shown in Scheme 2.

Table 3. Multicomponent reaction conditions by method of heating or microwave irradiation.

\begin{tabular}{|c|c|c|c|c|c|c|c|}
\hline \multirow{2}{*}{ Comp. } & \multicolumn{3}{|c|}{ Reagents } & \multicolumn{2}{|c|}{ Method $\backslash$ Reaction Time } & \multicolumn{2}{|c|}{ Method/Yield (\%) } \\
\hline & 3 & 6 & 4 & Conventional, $\mathrm{h}$ & MWI, min & Conventional & MWI \\
\hline $7 \mathbf{a}$ & 3 & 6 & $4 a$ & 30 & 50 & 51 & 65 \\
\hline $7 \mathbf{b}$ & 3 & 6 & $4 b$ & 28 & 50 & 59 & 68 \\
\hline $7 c$ & 3 & 6 & $4 c$ & 30 & 50 & 53 & 70 \\
\hline $7 d$ & 3 & 6 & $4 d$ & 28 & 50 & 62 & 73 \\
\hline $7 e$ & 3 & 6 & $4 e$ & 28 & 50 & 44 & 63 \\
\hline
\end{tabular}

Furthermore, in our progression in the development of the highly efficient method in the synthesis of newly fused heterocyclic compounds with expected biological activity. we report the synthesis of novel pyrrolo[2,1-b][1,3]benzothiazole derivatives 9a-e, Scheme 4, via microwave-assisted three-component reactions and the evaluation of their cytotoxicity, leading to the discovery of some new heterocycles with potent cytotoxic activity higher than or similar to doxorubicin as standard drug.

Initially, under microwave irradiation of three-component of 2-cyanomethyl -1,3benzothiazol 3, benzoyl cyanide 8 and, appropriate aldehyde such as 4-fluorobenzaldhyde $\mathbf{4 d}$ was employed to optimize the reaction conditions as shown in (Table 4). Firstly, (MWI, $100{ }^{\circ} \mathrm{C}, 25 \mathrm{~min}$ ) solvent screening showed that the usage of methanol or ethanol as polar solvents was beneficial while in dichloroethane no reaction occurred (entry 2). The presence of bases also increases the yield percentage as shown in Table 4. DBU was shown to be an effective base catalyst more than TEA. So, EtOH/DBU was preferred as the optimal solvent/catalyst system and $120^{\circ} \mathrm{C}$ was selected as the most convenient reaction temperature (Table 4 , entry 7 ) in view of the highest yield of $9 \mathbf{d}(87 \%)$. Under the optimized reaction conditions, various aldehydes $4 \mathbf{a}$-e were treated with 2-cyanomethyl-1,3-benzothiazol 3 and benzoyl cyanide 8, as illustrated in Table 4, while treatment of the three components under conventional heating took a long time and afforded a moderate yield. 


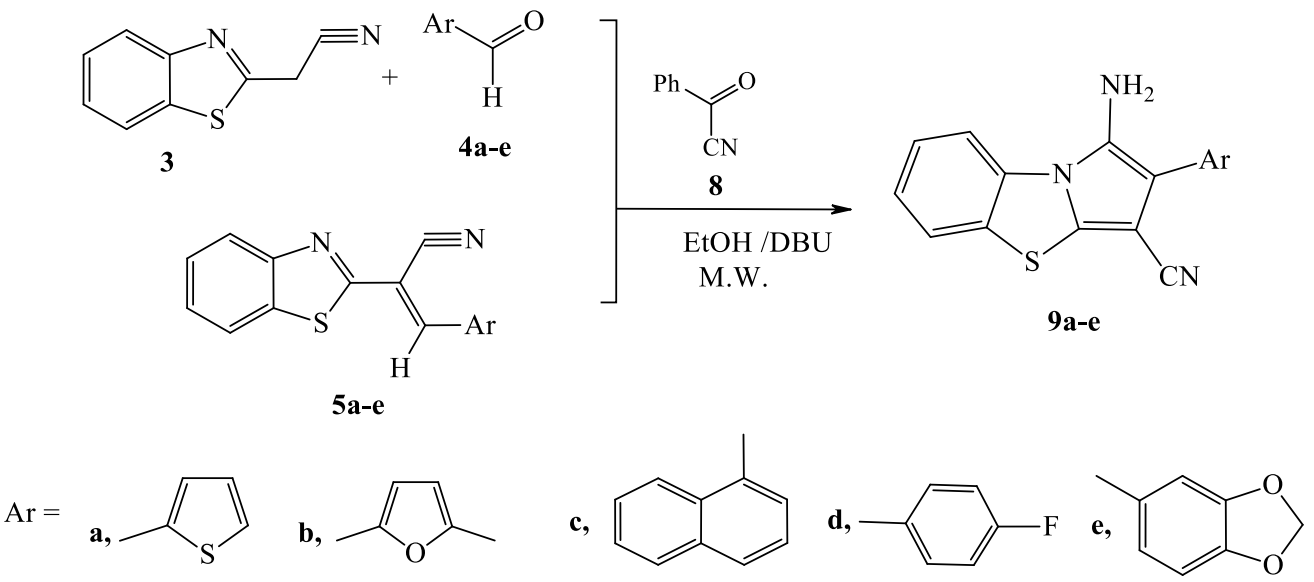

Scheme 4. Synthesis of 1-amino-pyrrolobenzothiazole-3-carbonitrile derivatives (9a-e) under microwave as assisted method.

Table 4. One pot three-component reaction optimization for the synthesis of 1-aminopyrrolobenzothiazole-3-carbonitrile derivatives $\mathbf{9 a - e . ~}$

\begin{tabular}{|c|c|c|c|c|c|c|c|}
\hline Entry & 3 eq. & 8 eq. & 4 eq. & Solvent & Method $/\left(\mathrm{T}^{\circ} \mathrm{C}\right)$ & Time, min & Yield (\%) \\
\hline 1 & 1 & 1 & $4 d, 1$ & $\mathrm{MeOH}$ & $\mathrm{MV}, 100^{\circ} \mathrm{C}$ & 25 & 61 \\
\hline 2 & 1 & 1 & $4 d, 1$ & DCE & $\mathrm{MV}, 100^{\circ} \mathrm{C}$ & 25 & NR \\
\hline 3 & 1 & 1 & $4 d, 1$ & EtOH & $\mathrm{MV}, 100^{\circ} \mathrm{C}$ & 25 & 68 \\
\hline 4 & 1 & 1 & $4 d, 1$ & EtOH/TEA & $\mathrm{MV}, 100^{\circ} \mathrm{C}$ & 25 & 73 \\
\hline 5 & 1 & 1 & $4 d, 1$ & EtOH/TEA & $\mathrm{MV}, 120^{\circ} \mathrm{C}$ & 25 & 78 \\
\hline 6 & 1 & 1 & $4 d, 1$ & EtOH/DBU(1 eq.) & $\mathrm{MV}, 100{ }^{\circ} \mathrm{C}$ & 25 & 75 \\
\hline 7 & 1 & 1 & $4 \mathrm{~d}, 1$ & $\mathrm{EtOH} / \mathrm{DBU}$ (1 eq.) & $\mathrm{MV}, 120^{\circ} \mathrm{C}$ & 25 & 87 \\
\hline 8 & 1 & 1 & $4 a, 1$ & $\mathrm{EtOH} / \mathrm{DBU}$ (1 eq.) & $\mathrm{MV}, 120^{\circ} \mathrm{C}$ & 25 & 72 \\
\hline 9 & 1 & 1 & $4 b, 1$ & $\mathrm{EtOH} / \mathrm{DBU}$ (1 eq.) & $\mathrm{MV}, 120^{\circ} \mathrm{C}$ & 25 & 70 \\
\hline 10 & 1 & 1 & $4 c, 1$ & $\mathrm{EtOH} / \mathrm{DBU}$ (1 eq.) & $\mathrm{MV}, 120^{\circ} \mathrm{C}$ & 25 & 71 \\
\hline 11 & 1 & 1 & $4 \mathrm{e}, 1$ & $\mathrm{EtOH} / \mathrm{DBU}$ (1 eq.) & $\mathrm{MV}, 120^{\circ} \mathrm{C}$ & 25 & 66 \\
\hline 12 & 1 & 1 & $4 a, 1$ & EtOH/TEA & Heating & $20 \mathrm{~h}$ & 62 \\
\hline 13 & 1 & 1 & $4 b, 1$ & $\mathrm{EtOH} / \mathrm{TEA}$ & Heating & $22 \mathrm{~h}$ & 59 \\
\hline 14 & 1 & 1 & $4 c, 1$ & $\mathrm{EtOH} / \mathrm{TEA}$ & Heating & $20 \mathrm{~h}$ & 63 \\
\hline 15 & 1 & 1 & $4 d, 1$ & $\mathrm{EtOH} / \mathrm{TEA}$ & Heating & $19 \mathrm{~h}$ & 68 \\
\hline 16 & 1 & 1 & $4 \mathrm{e}, 1$ & $\mathrm{EtOH} / \mathrm{TEA}$ & Heating & $24 \mathrm{~h}$ & 52 \\
\hline
\end{tabular}

A reasonable reaction mechanism for the synthesis of 1-amino pyrrolobenzothiazole-3carbonitrile derivatives $\mathbf{9 a - e}$ is shown in Scheme 5. The reaction involves a base-catalyzed two-step formation of 2-arylidene cyanomethyl 1,3-benzothiazoles via a Knoevenagel condensation between 2-cyanomethyl-1,3-benzothiazol and aldehydes, followed by [4+1] cycloaddition of benzoyl cyanide.

Finally, as illustrated in Table 5, the corresponding products 9a-e were successfully achieved in high yield compared with the three-component reaction through the treatment of the reactive intermediates $\mathbf{5 a}-\mathbf{e}$ with benzoyl cyanide $\mathbf{8}$ under microwave irradiation at $120{ }^{\circ} \mathrm{C}$ for $20-25 \mathrm{~min}$ in EtOH/DBU, while conventional heating in ethanol/TEA took a long time. As is evident, the yield afforded from the treatment of $5 \mathbf{a}-\mathbf{e}$ with benzoyl cyanide 8 was the best, compared to the yield from multicomponent reactions under microwave irradiation. So, it is now settled that microwaves can greatly speed up reactions and improve overall yield. 


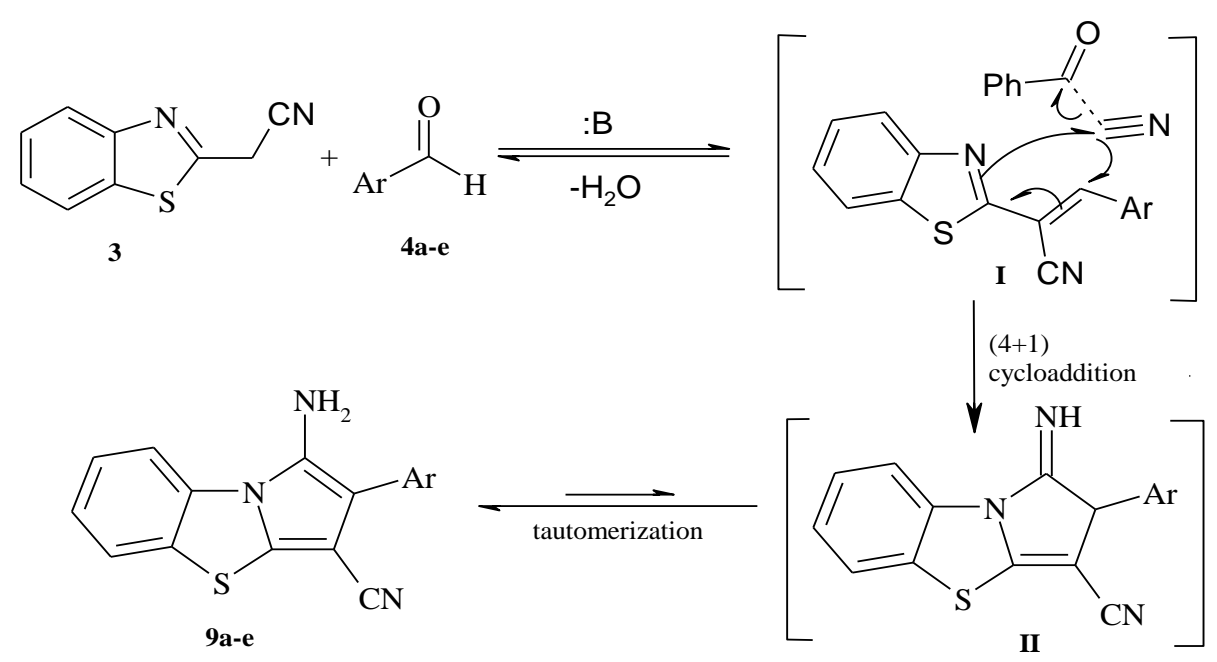

Scheme 5. Synthetic mechanism of pyrrolobenzothiazole-3-carbonitrile derivatives 9a-e.

Table 5. Reaction condition for the synthesis of $\mathbf{9 a}-\mathbf{e}$.

\begin{tabular}{ccccccc}
\hline \multirow{2}{*}{ Comp. } & \multicolumn{2}{c}{ Reagents } & \multicolumn{2}{c}{ Method $\backslash$ Reaction Time } & \multicolumn{2}{c}{ Method/Yield (\%) } \\
\cline { 2 - 7 } & $\mathbf{5}$ & $\mathbf{8}$ & Conventional, h & MWI, min. & Conventional & MWI \\
\hline 9a & $\mathbf{5 a}$ & $\mathbf{8}$ & 15 & 25 & 70 & 82 \\
9b & $\mathbf{5 b}$ & $\mathbf{8}$ & 13 & 20 & 68 & 79 \\
9c & $\mathbf{5 c}$ & $\mathbf{8}$ & 15 & 22 & 70 & 85 \\
9d & $\mathbf{5 d}$ & $\mathbf{8}$ & 12 & 21 & 74 & 90 \\
9e & 5e & $\mathbf{8}$ & 14 & 23 & 65 & 78 \\
\hline
\end{tabular}

\subsection{Biological Activities}

\subsubsection{Antimicrobial Activity and Structure Activity Relationship}

The values of MIC of the synthesized compounds against the tested microorganisms are displayed in Tables 6 and 7. Benzothiazole arylidine derivatives 5a-e exhibited good to moderate antimicrobial activities. These derivatives increased the antimicrobial activity when treated with 6-aminothiouracil to afford 2,3-dihydropyrido [2,3-d] pyrimidine-4-one derivatives. The investigations showed significant inhibitory effects against bacteria with the majority of the compounds with MIC values of $\left(4-20 \mu \mathrm{mol} \mathrm{L}^{-1}\right)$ (Table 6). It was found that compounds $7 \mathbf{a}, \mathbf{d}$ were found to be more potent against bacteria with $M I C$ value ranging from (4-12 $\left.\mu \mathrm{mol} \mathrm{L}{ }^{-1}\right)$ than cefotaxime with MIC value $\left(6-12 \mu \mathrm{mol} \mathrm{L}{ }^{-1}\right)$, while compounds 7b, 7c and 7e exhibited good activity against all the bacterial strains. This high efficacy may be attributed to the presence of a benzothiazol and thiophene moiety as compound 7a and the presence of an electron withdrawing group (fluoro) in the para-position of the phenyl ring attached to the pyridopyrimidine backbone $\mathbf{7 d}$. Compound $7 \mathbf{a}$ had equipotent activity with $\operatorname{MIC}\left(6,12 \mu \mathrm{mol} \mathrm{L}{ }^{-1}\right)$ as cefotaxime against Bacillus subtilis and Chlamydia pneumonia, respectively. Compound 7 e was also equipotent with $M I C(8 \mu \mathrm{mol} \mathrm{L}-1)$ as cefotaxime against Salmonella typhi. Pyrrolo[2,1-b][1,3]benzothiazole derivatives 9a-e could effectively inhibit the growth of the tested bacteria strains. Compound 9a was more potent against Staphylococcus aureus while it had equipotent efficacy against Bacillus subtilis and Chlamydia pneumonia to cefotaxime; this was attributed to the presence of pyrrolo [2,1-b][1,3]benzothiazole with thiophene moiety as a side chain. Compound 9d with MIC (4-10 $\left.\mu \mathrm{mol} \mathrm{L}{ }^{-1}\right)$ had exceptional activity toward all bacteria due to the presence of pyrrolobenzothiazole with $p$-fluorophenyl substituent which increased the antibacterial potency compared to the reference drug. On the other hand, compounds 9b, 9c and 9e exhibited good inhibition activity against all bacterial strains (Table 6). 
Table 6. Minimum inhibitory concentration $\left(M I C, \mu \mathrm{mol} \mathrm{L}^{-1}\right)$ of newly synthesized compounds against bacteria.

\begin{tabular}{|c|c|c|c|c|c|c|}
\hline \multirow[b]{2}{*}{ Entry } & \multicolumn{3}{|c|}{ Gram-Positive Bacteria } & \multicolumn{3}{|c|}{ Gram-Negative Bacteria } \\
\hline & $\begin{array}{c}\text { Staphylococcus } \\
\text { Aureus }\end{array}$ & $\begin{array}{l}\text { Streptococcus } \\
\text { Pneumonia }\end{array}$ & $\begin{array}{l}\text { Bacillus } \\
\text { Subtilis }\end{array}$ & $\begin{array}{l}\text { Chlamydia } \\
\text { Pneumonia }\end{array}$ & $\begin{array}{l}\text { Escherichia } \\
\text { Coli }\end{array}$ & $\begin{array}{l}\text { Salmonella } \\
\text { Typhi }\end{array}$ \\
\hline $5 a$ & 14 & 10 & 10 & 18 & 12 & 12 \\
\hline $5 b$ & 16 & 16 & 19 & 16 & 15 & 20 \\
\hline $5 c$ & 19 & 16 & 12 & 19 & 18 & 15 \\
\hline $5 d$ & 12 & 9 & 8 & 16 & 13 & 15 \\
\hline $5 e$ & 20 & 18 & 18 & 17 & 14 & 12 \\
\hline $7 \mathbf{a}$ & 8 & 4 & 6 & 12 & 5 & 10 \\
\hline $7 \mathrm{~b}$ & 12 & 10 & 8 & 15 & 12 & 14 \\
\hline $7 \mathrm{c}$ & 12 & 10 & 10 & 14 & 10 & 10 \\
\hline $7 d$ & 6 & 5 & 6 & 10 & 4 & 8 \\
\hline $7 e$ & 14 & 12 & 9 & 12 & 10 & 10 \\
\hline $9 a$ & 8 & 10 & 6 & 12 & 8 & 10 \\
\hline $9 b$ & 14 & 10 & 10 & 14 & 10 & 12 \\
\hline $9 \mathrm{c}$ & 16 & 12 & 12 & 14 & 10 & 10 \\
\hline $9 d$ & 10 & 4 & 6 & 8 & 5 & 8 \\
\hline $9 e$ & 14 & 10 & 10 & 13 & 10 & 12 \\
\hline Cefotaxime & 10 & 6 & 6 & 12 & 6 & 8 \\
\hline
\end{tabular}

Table 7. Minimum inhibitory concentration $\left(M I C, \mu \mathrm{mol} \mathrm{L}^{-1}\right)$ of newly synthesized compounds against fungi.

\begin{tabular}{cccc}
\hline Comp. & Aspergillus Flavus & Candida Albicans & Ganoderma Lucidum \\
\hline $\mathbf{5 a}$ & 10 & 12 & 10 \\
$\mathbf{5 b}$ & 11 & 13 & 14 \\
$\mathbf{5 c}$ & 14 & 18 & 10 \\
$\mathbf{5 d}$ & 12 & 12 & 13 \\
$\mathbf{5 e}$ & 9 & 10 & 12 \\
$\mathbf{7 a}$ & 8 & 10 & 9 \\
$\mathbf{7 b}$ & 12 & 15 & 18 \\
$\mathbf{7 c}$ & 12 & 16 & 12 \\
$\mathbf{7 d}$ & 8 & 10 & 10 \\
$\mathbf{7 e}$ & 9 & 18 & 20 \\
$\mathbf{9 a}$ & 8 & 4 & 8 \\
$\mathbf{9 b}$ & 9 & 10 & 12 \\
$\mathbf{9 c}$ & 16 & 20 & 11 \\
$\mathbf{9 d}$ & 6 & 5 & 4 \\
$\mathbf{9 e}$ & 10 & 10 & 10 \\
Fluconazole & 6 & 8 & 6 \\
\hline
\end{tabular}

The newly synthesized compounds were evaluated for their antifungal activity against three fungal strains displayed in (Table 7). Most of the synthesized compounds exhibited good to moderate inhibition activities against all the fungal strains. Compound $9 \mathbf{d}$ exhibited more potent activity than fluconazole against Candida albicans and Ganoderma lucidum while it had equipotent activity against Aspergillus flavus. Compound 9a exhibited stronger activity than fluconazole against Candida albicans and excellent activity against Aspergillus flavus and Ganoderma lucidum. Compound $\mathbf{9 b}$ had good inhibition activity against Aspergillus flavus and Candida albicans but moderate activity toward Ganoderma lucidum. Compound $9 e$ also had promising activity against all fungal strains.

Compounds $7 \mathbf{a}, \mathbf{d}$ had good inhibition activity against all fungus, while compounds $5 \mathbf{a}-\mathbf{e}, 7 \mathbf{b}, 7 \mathbf{c}$ and $7 \mathrm{e}$ exhibited good to moderate activities. The introduction of benzothiazole, thiophene, and p-fluorophenyl moieties to the pyridopyrimidine derivatives and 
the presence of pyrrolobenzothiazole derivatives with thiophene and $p$-fluorophenyl side chains might be responsible for the antifungal activity enhancement of these compounds.

\subsubsection{Cytotoxicity Screening and Structure Activity Relationship (SAR)}

The cytotoxic activity of all the newly synthesized compounds benzothiazole arylidine 5a-e, pyrido[2,3-d]pyrimidine 7a-e and pyrrolo[2,1-b][1,3] benzothiazole derivatives 9a-e were evaluated against three tumor cell lines (human lung cell NCI-H460, liver cancer HepG2 and colon cancer HCT-116) by MTT assay. The three human cancer cell lines were provided by the National Cancer Institute (NCI, Cairo, Egypt). Doxorubicin was used as the positive control. The cytotoxic activities are expressed as the median growth inhibitory concentration $\left(\mathrm{IC}_{50}\right)$ and are provided in (Table 8). From the results, it is evident that most of the newly synthesized compounds showed potent to moderate cytotoxic activity against the three tumor cell lines. The results of the series of compound $\mathbf{5}$ indicated that the type of the side chain on the benzothiazole arylidine derivatives occupied significant roles in the cytotoxic activity. Compounds 5a with $\mathrm{IC}_{50}$ values of $\left(3.61,3.14\right.$ and $\left.4.20 \mu \mathrm{mol} \mathrm{L}{ }^{-1}\right)$ and $\mathbf{5 d}$ with $\mathrm{IC}_{50}$ values of $\left(3.04,3.20\right.$ and $\left.3.38 \mu \mathrm{mol} \mathrm{L}{ }^{-1}\right)$ showed good antitumor activity toward all tumor cell lines, while the other compounds $5 \mathrm{~b}, 5 \mathrm{c}$ and $5 \mathrm{e}$ exhibited moderate activity in the range of $\left(\mathrm{IC}_{50}=5.82-10.20 \mu \mathrm{mol} \mathrm{L}{ }^{-1}\right)$ compared to doxorubicin.

Table 8. Inhibition of the growth of human lung cell NCI-H460, liver cancer (HepG2), colon cancer HCT-116 tumor cell lines by synthesized compounds.

\begin{tabular}{|c|c|c|c|}
\hline \multirow{2}{*}{ Comp. } & \multicolumn{3}{|c|}{$\mathrm{IC}_{50}(\mu \mathrm{mol} \mathrm{L}-1)^{a}$} \\
\hline & NCI-H460 & HepG2 & НСТ-116 \\
\hline $5 a$ & $3.61 \pm 0.28$ & $3.14 \pm 0.16$ & $4.20 \pm 0.75$ \\
\hline $5 b$ & $5.90 \pm 0.14$ & $5.82 \pm 0.16$ & $6.42 \pm 0.17$ \\
\hline $5 c$ & $10.20 \pm 2.68$ & $9.10 \pm 2.26$ & $9.54 \pm 1.28$ \\
\hline $5 d$ & $3.04 \pm 0.15$ & $3.20 \pm 0.18$ & $3.38 \pm 0.27$ \\
\hline $5 e$ & $7.50 \pm 0.78$ & $8.20 \pm 0.44$ & $9.30 \pm 2.46$ \\
\hline $7 a$ & $0.66 \pm 0.08$ & $0.45 \pm 0.04$ & $0.70 \pm 0.14$ \\
\hline $7 \mathrm{~b}$ & $2.56 \pm 0.18$ & $2.89 \pm 0.19$ & $2.68 \pm 0.12$ \\
\hline $7 c$ & $4.09 \pm 0.33$ & $5.35 \pm 0.60$ & $5.58 \pm 0.58$ \\
\hline $7 d$ & $0.28 \pm 0.04$ & $0.39 \pm 0.04$ & $0.14 \pm 0.04$ \\
\hline $7 e$ & $2.60 \pm 0.24$ & $3.00 \pm 0.13$ & $3.08 \pm 0.64$ \\
\hline $9 a$ & $1.10 \pm 0.11$ & $0.49 \pm 0.06$ & $0.89 \pm 0.06$ \\
\hline $9 b$ & $3.20 \pm 0.18$ & $3.54 \pm 0.62$ & $3.89 \pm 0.73$ \\
\hline $9 c$ & $6.08 \pm 0.42$ & $6.90 \pm 0.13$ & $7.20 \pm 0.46$ \\
\hline 9d & $0.45 \pm 0.06$ & $0.47 \pm 0.06$ & $0.59 \pm 0.10$ \\
\hline $9 e$ & $3.90 \pm 0.17$ & $4.08 \pm 0.63$ & $4.50 \pm 0.54$ \\
\hline Doxorubicin & $1.98 \pm 0.17$ & $0.52 \pm 0.06$ & $1.12 \pm 0.13$ \\
\hline
\end{tabular}

${ }^{\mathrm{a}} \mathrm{IC}_{50}: 50 \%$ inhibitory concentration. Mean \pm SEM of three independent experiments performed in triplicate.

The series of 2,3-dihydropyrido[2,3-d]pyrimidine-4-one derivatives 7a-e exhibited higher cytotoxic activity than the series of pyrrolo $[2,1-b][1,3]$ benzothiazole $9 a-e$. Table 8 shows 2,3-dihydropyrido[2,3-d]pyrimidine-4-one 7a containing benzothiazol and thiophene as a biologically active side chain with $\mathrm{IC}_{50}$ values of $(0.66,0.45$ and $0.70 \mu \mathrm{mol} \mathrm{L}-1)$, benzothiazol and p-fluorophenyl moieties $\mathbf{7 d}$ with $\mathrm{IC}_{50}$ values of $(0.28,0.39$ and $0.14 \mu \mathrm{mol}$ $\mathrm{L}^{-1}$ ), pyrrolo[2,1-b][1,3]benzothiazole 9a with benzothiazol and thiophene with $\mathrm{IC}_{50}$ values of $\left(1.10,0.49\right.$ and $\left.0.89 \mu \mathrm{mol} \mathrm{L}{ }^{-1}\right)$, benzothiazol and p-fluorophenyl $9 \mathrm{~d}$ side chain moieties with $\mathrm{IC}_{50}$ values of $\left(0.45,0.47\right.$ and $\left.0.59 \mu \mathrm{mol} \mathrm{L}^{-1}\right)$ were found to be more potent and efficacious than the reference drug doxorubicin with $\mathrm{IC}_{50}$ values of $\left(1.98,0.52\right.$ and $\left.1.12 \mu \mathrm{mol} \mathrm{L}^{-1}\right)$. It was noticeable that the presence of side chain $p$-fluorophenyl improved the antitumor activity more than thiophene side chain in addition to the basic skeleton.

In addition, 5-methylfuranyl $7 \mathbf{b}$ with $\mathrm{IC}_{50}$ values of $(2.56,2.89,2.68), 5$-piperonyl-2,3dihydropyrido[2,3-d]pyrimidine-4-one and $7 \mathbf{e}\left(2.60,3.00\right.$ and $\left.3.08 \mu \mathrm{mol} \mathrm{L}^{-1}\right)$ exhibited good cytotoxic effect towards the three tumor cell lines. On the other hand, 5-methylfuranyl 9b 
with $\mathrm{IC}_{50}$ (3. 20, 3.54 and $3.89 \mu \mathrm{mol} \mathrm{L}{ }^{-1}$ ) and 2-piperonyl pyrrolo[2,1-b][1,3]benzothiazole 9e with $\operatorname{IC50}\left(3.90,4.08\right.$ and $\left.4.50 \mu \mathrm{mol} \mathrm{L}^{-1}\right)$ had good antitumor activity against all tumor cell lines. Compounds with 5-naphthalenyl side chain in both 2,3-dihydropyrido[2,3d]pyrimidine-4-one 7c and pyrrolo[2,1-b][1,2]benzothiazole 9c showed moderate antitumor activity. From the above structure activity relationships (SAR), the most selective 2,3-dihydropyrido[2,3-d]pyrimidine-4-one and pyrrolo [2,1-b] [1,3]benzothiazole on the studied cancer cell lines were bearing $\mathrm{p}$-fluorophenyl and thiophene moieties. Thus, among the promising candidates against cancer cell lines compounds $\mathbf{7 a}, \mathbf{7 d}, \mathbf{9 a}$, and $\mathbf{9 d}$ ended up being the best pharmacophores for developing a new drug candidate for cancer.

Generally, the type of substituent plays an important role in antitumor activity and the presence of the basic skeleton of fused heterocyclic compounds improves the cytotoxic activity in cancer cells.

\subsubsection{Antioxidant Activity Screening Assay}

A series of 2,3-dihydropyrido[2,3-d]pyrimidine-4-one 7a-e and pyrrolo[2,1-b][1,3] benzothiazole 9a-e derivatives were tested for antioxidant activity as reflected in the ability to inhibit lipid peroxidation in rat brain and kidney homogenates by using (3ethylbenzthiazoline-6-sulfonic acid) ABTS free radical scavenging, see Table 9. Compounds 7a (91.2\%), 7d (92.8\%) and 9d (90.4\%) exhibited potent inhibition higher than Trolox (89.5\%), while compound 9a (88.7\%) showed nearly equipotent inhibition activity. On the other hand, the remaining compounds $7 \mathbf{b}, 7 \mathrm{c}, 7 \mathrm{e}, 9 \mathrm{~b}, 9 \mathrm{c}$ and $9 \mathrm{e}$ showed good antioxidant activities Table 9.

Table 9. Antioxidant activity and bleomycin-dependent DNA damage assay.

\begin{tabular}{cccc}
\hline Comp. & Absorbance & ABTS Inhibition(\%) & Bleomycin-Dependent DNA Damage \\
\hline 7a & 0.06 & 91.2 & 0.053 \\
7b & 0.20 & 78.3 & 0.121 \\
7c & 0.28 & 75.3 & 0.128 \\
7d & 0.03 & 92.8 & 0.045 \\
7e & 0.28 & 68.0 & 0.146 \\
9a & 0.10 & 88.7 & 0.069 \\
9b & 0.32 & 69.3 & 0.186 \\
9c & 0.22 & 65.5 & 0.179 \\
9d & 0.08 & 90.4 & 0.064 \\
9e & 0.26 & 72.2 & 0.132 \\
Trolox & 0.04 & 89.5 & 0.067 \\
\hline
\end{tabular}

All experiments were performed three times.

\subsubsection{Bleomycin-Dependent DNA Damage}

The pro-oxidant activities of compounds $7 \mathbf{a}-\mathbf{e}$ and $\mathbf{9 a}-\mathbf{e}$ were assessed by their effects on bleomycin-induced DNA damage. Analysis of the data in Table 9 showed that, compounds $7 \mathbf{a}(0.053), 7 \mathbf{d}(0.045)$, and $9 \mathbf{d}(0.064)$ were found to be more potent than the reference drug Trolox (0.067). Moreover, compound 9a (0.069) had almost equipotent activity, that means these compounds have great ability to protect DNA from the damage induced by bleomycin. The rest of compounds $7 b, 7 c, 7 e, 9 b, 9 c$ and $9 e$ exhibited excellent protection against DNA damage.

\section{Materials and Methods}

\subsection{Reagents and Materials}

Melting points were recorded on an advanced melting point apparatus, SMP30, Stuart (Bibby Scientific, London, UK). Microanalytical data were gathered with a Vario Elementar apparatus (Shimadzu-Japan). Elemental analyses of all compounds were within $\pm 0.4 \%$ of the theoretical values. The IR spectra $(\mathrm{KBr})$ were recorded on a Perkin Elmer 1650 spectrometer (USA). ${ }^{1} \mathrm{H}$ and ${ }^{13} \mathrm{C}$ NMR spectra (500 MHz for ${ }^{1} \mathrm{H}$ and $125 \mathrm{MHz}$ for ${ }^{13} \mathrm{C} \mathrm{NMR}$ ) were recorded on JEOL ECA-500 (Shimadzu) instruments. 
Chemical shifts were expressed in ppm relative to $\mathrm{SiMe}_{4}$ as an internal standard in DMSO- $d_{6}$ or $\left(\mathrm{CDCl}_{3}\right)$ as a solvent. Mass spectra were recorded on a $70 \mathrm{eV}$ Finnigan SSQ 7000 spectrometer (Thermo-Instrument System Incorporation, USA). Follow up of the reaction and the purity of the compounds was checked on aluminum plates coated with silica gel (Merck, Germany) on Microwave Advanced Flexible Synthesis Platform 1900 W (flexiWAVE-Milestone, Italy), producing continuous irradiation and equipped with a simultaneous external air-cooling system. Chemicals and solvents (Analar $\geq 99 \%$ ) were purchased from Sigma-Aldrich (USA).

\subsection{Syntheses}

2-(1,3-benzothiazol-2-yl)-3-(aryl)prop-2-enenitrile (5a-e).

General procedure. A mixture of compound $3(0.87 \mathrm{~g}, 5 \mathrm{mmol})$, (5 mmol) of the appropriate aromatic aldehyde (thiophene-2-carboxaldehyde, 5-methylfuran-carbox- aldhyde, 1-naphthaldhyde, 4-fluorobenzaldhyde, and piperonal) $4 \mathbf{a}-\mathbf{e}$ and TEA in ethanol was subjected to MWI at $60{ }^{\circ} \mathrm{C}$ for 4-8 min. The progress of the reaction was followed by TLC (petroleum ether (80-90): ethyl acetate, ratio:3:1). After cooling, solids were obtained, filtered, and recrystallized from a proper solvent to give $5 \mathbf{a}-\mathbf{e}$, respectively.

2-(1,3-benzothiazol-2-yl)-3-(thiophen-2-yl)prop-2-enenitrile (5a).

Green powder, crystallized from cyclohexane, mp. $153-155^{\circ} \mathrm{C} ; \mathrm{IR}\left(\mathrm{KBr}, \mathrm{cm}^{-1}\right) ; 3108$ (CH aryl), $2212(\mathrm{CN}), 1600(\mathrm{C}=\mathrm{N}) ;{ }^{1} \mathrm{H} \mathrm{NMR}\left(500 \mathrm{MHz}, \mathrm{CDCl}_{3}, \delta, \mathrm{ppm}\right) ; 7.25(\mathrm{~s}, 1 \mathrm{H}$, thiophene), $7.42(\mathrm{t}, 1 \mathrm{H}, \mathrm{Ar}-H), 7.52(\mathrm{t}, 1 \mathrm{H}, \mathrm{Ar}-\mathrm{H}), 7.71(\mathrm{~d}, 1 \mathrm{H}, J=4.92 \mathrm{~Hz}$, thiophene), $7.82(\mathrm{~d}$, $1 \mathrm{H}, J=5.1 \mathrm{~Hz}$, thiophene), $7.91(\mathrm{~d}, 1 \mathrm{H}, J=8.01 \mathrm{~Hz}, \mathrm{Ar}-H), 8.05(\mathrm{~d}, 1 \mathrm{H}, J=8.01 \mathrm{~Hz}, \mathrm{Ar}-H)$, $8.40(\mathrm{~s}, 1 \mathrm{H},=\mathrm{CH})$,; Its MS (m/z), $268\left(\mathrm{M}^{+}\right) ; \mathrm{C}_{14} \mathrm{H}_{8} \mathrm{~N}_{2} \mathrm{~S}_{2}$ (268.3); Anal. Calcd.; \% C: 62.66, \% $\mathrm{H}: 3.00, \%$ N: 10.44; found \% C: 62.64, \% H: 2.98, \% N: 10.41. (see Supporting Information).

2-(1,3-benzothiazol-2-yl)-3-(5-methylfuran-2-yl)prop-2-enenitrile (5b).

Brown powder, crystallized from ethanol, mp. 150-151 ${ }^{\circ} \mathrm{C}$; IR $\left(\mathrm{KBr}, \mathrm{cm}^{-1}\right) ; 2934,2899$ (CH aliphatic), 3054 (CH aryl), $2226(\mathrm{CN}), 1588(\mathrm{C}=\mathrm{N}) ;{ }^{1} \mathrm{H}$ NMR $\left(500 \mathrm{MHz}, \mathrm{CDCl}_{3}, \delta\right.$, ppm); $2.44\left(\mathrm{~s}, 3 \mathrm{H}, \mathrm{CH}_{3}\right), 6.27(\mathrm{~d}, 1 \mathrm{H}, J=5.6 \mathrm{~Hz}$, furan), $7.19(\mathrm{~d}, 1 \mathrm{H}, \mathrm{J}=5.68 \mathrm{~Hz}$, furan), $7.44(\mathrm{t}, 1 \mathrm{H}$, Ar- $H), 7.48(\mathrm{t}, 1 \mathrm{H}, \mathrm{Ar}-\mathrm{H}), 7.84(\mathrm{~d}, 1 \mathrm{H}, J=8.10 \mathrm{~Hz}, \mathrm{Ar}-\mathrm{H}), 7.92(\mathrm{~s}, 1 \mathrm{H},=\mathrm{CH}), 8.00(\mathrm{~d}, 1 \mathrm{H}, J=$ $8.10 \mathrm{~Hz}, \mathrm{Ar}-\mathrm{H})$; Its MS (m/z), $266\left(\mathrm{M}^{+}\right) ; \mathrm{C}_{15} \mathrm{H}_{10} \mathrm{~N}_{2} \mathrm{OS}$ (266.3); Anal. Calcd.; \% C: 67.65, \% H: $3.78, \% \mathrm{~N}: 10.52$; found \% C: $67.63, \% \mathrm{H}: 3.75, \% \mathrm{~N}: 10.49$.

2-(1,3-benzothiazol-2-yl)-3-(naphthalen-1-yl)prop-2-enenitrile (5c).

Pale yellow powder, crystallized from dioxane, mp. $128-130{ }^{\circ} \mathrm{C}$; IR $\left(\mathrm{KBr}, \mathrm{cm}^{-1}\right) ; 3050$ (CH aryl), $2218(\mathrm{CN}), 1587(\mathrm{C}=\mathrm{N}) ;{ }^{1} \mathrm{H} \mathrm{NMR}\left(500 \mathrm{MHz}, \mathrm{CDCl}_{3}, \delta, \mathrm{ppm}\right) ; 7.61$ (t, 1H, ArH),7.80 (m, 4H, Ar-H), $8.02(\mathrm{~m}, 2 \mathrm{H}, \mathrm{Ar}-\mathrm{H}), 8.11(\mathrm{~d}, 1 \mathrm{H}, J=8.76 \mathrm{~Hz}, \mathrm{Ar}-H), 8.12(\mathrm{~m}, 2 \mathrm{H}$, $\operatorname{Ar}-H), 8.14(\mathrm{~d}, 1 \mathrm{H}, J=8.76 \mathrm{~Hz}, \mathrm{Ar}-\mathrm{H}), 9.08$ (s, 1H, =CH); Its MS (m/z), $312\left(\mathrm{M}^{+}, 80 \%\right)$; $\mathrm{C}_{20} \mathrm{H}_{12} \mathrm{~N}_{2} \mathrm{~S}$ (312.3); Anal. Calcd.; \% C: 76.90, \% H: 3.87, \% N: 8.97; found \% C: 76.88, \% H: $3.85, \% \mathrm{~N}: 8.94$.

2-(1,3-benzothiazol-2-yl)-3-(4-fluorophenyl)prop-2-enenitrile (5d).

Yellow powder, crystallized from ethanol, mp. $161-163{ }^{\circ} \mathrm{C} ; \mathrm{IR}\left(\mathrm{KBr}, \mathrm{cm}^{-1}\right) ; 3054(\mathrm{CH}$ aryl), $2226(\mathrm{CN}), 1588(\mathrm{C}=\mathrm{N}) ;{ }^{1} \mathrm{H} \mathrm{NMR}\left(500 \mathrm{MHz}, \mathrm{CDCl}_{3}, \delta, \mathrm{ppm}\right) ; 7.20$ (m, 2H, Ar-H), 7.42 $(\mathrm{t}, 1 \mathrm{H}, \mathrm{Ar}-\mathrm{H}), 7.50(\mathrm{t}, 1 \mathrm{H}, \mathrm{Ar}-\mathrm{H}), 7.90(\mathrm{~d}, 1 \mathrm{H}, J=8.10 \mathrm{~Hz}, \mathrm{Ar}-H), 8.04$ (m, 3H, Ar-H), 8.19 (s, $1 \mathrm{H},=\mathrm{CH})$; Its MS (m/z), $280\left(\mathrm{M}^{+}, 73 \%\right) ; \mathrm{C}_{16} \mathrm{H}_{9} \mathrm{FN}_{2} \mathrm{~S}$ (280.3); Anal. Calcd.; \% C: 68.55, \% H: 3.24, \% N: 9.99; found \% C: 68.54, \% H: 3.22, \% N: 9.97.

2-(1,3-benzothiazol-2-yl)-3-(piperon-2-yl)prop-2-enenitrile (5e).

Yellow powder, crystallized from dioxane, mp. 222-224 ${ }^{\circ} \mathrm{C}$; IR $\left(\mathrm{KBr}, \mathrm{cm}^{-1}\right) ; 2938,2874$ (CH aliphatic), 3054 (CH aryl), $2223(\mathrm{CN}), 1587(\mathrm{C}=\mathrm{N}) ;{ }^{1} \mathrm{H} \mathrm{NMR}\left(500 \mathrm{MHz}, \mathrm{CDCl}_{3}, \delta, \mathrm{ppm}\right)$; $6.08\left(\mathrm{~s}, 2 \mathrm{H}, \mathrm{O}-\mathrm{CH}_{2}-\mathrm{O}\right), 6.91(\mathrm{~d}, 1 \mathrm{H}, \mathrm{J}=7.05 \mathrm{~Hz}, \mathrm{Ar}-\mathrm{H}), 7.41-7.45(\mathrm{~m}, 2 \mathrm{H}, \mathrm{Ar}-H), 7.50-7.51(\mathrm{t}$, $1 \mathrm{H}, \mathrm{Ar}-H), 7.73(\mathrm{~s}, 1 \mathrm{H}, \mathrm{Ar}-H), 7.89(\mathrm{~d}, 1 \mathrm{H}, J=6.9 \mathrm{~Hz}, \mathrm{Ar}-H), 8.05(\mathrm{~d}, 1 \mathrm{H}, J=6.9 \mathrm{~Hz}, \mathrm{Ar}-H)$, 
$8.13(\mathrm{~s}, 1 \mathrm{H},=\mathrm{CH})$; Its MS (m/z), $306\left(\mathrm{M}^{+}, 66 \%\right) ; \mathrm{C}_{17} \mathrm{H}_{10} \mathrm{~N}_{2} \mathrm{O}_{2} \mathrm{~S}$ (306.3); Anal. Calcd.; \% C: 66.64, \% H: 3.92, \% N: 9.14; found \% C: 66.62, \% H: 3.90, \% N: 9.13.

7-amino-6-(1,3-benzothiazol-2-yl)-5-(aryl)-2-thioxo-2,3dihydropyrido[2,3-d]pyrimidin-4(1H)-one $(7 \mathbf{a}-\mathbf{e})$.

General procedure: (Method 1) under microwave irradiation.

(Method 1a): A mixture of compounds 5a-e $(5 \mathrm{mmol})$ and 6-aminothiouracil 6 (0.7 $\mathrm{g}$, $5 \mathrm{mmol}$ ) in DMF was placed in a microwave process vial. The vial was closed and subjected to microwave irradiation for $25 \mathrm{~min}$ at $150{ }^{\circ} \mathrm{C} /$ or in EtOH/TEA for $45 \mathrm{~min}$ at $100{ }^{\circ} \mathrm{C}$. The progress of the reaction was followed by TLC. After cooling to room temperature, the solid formed was filtered off, washed with ethanol, dried, and crystallized from DMF.

(Method 1b): A mixture of 2-cyanomethyl-1,3-benzothiazol 3 (0.87 g, $5 \mathrm{mmol})$, 6-amino thiouracil 6 (0.7 g, $5 \mathrm{mmol})$, and appropriate aldehydes $4 \mathbf{a}-\mathbf{e}(5 \mathrm{mmol})$ in DMF was placed in a microwave process vial. The vial was closed and subjected to microwave irradiation for $50 \mathrm{~min}$ at $150{ }^{\circ} \mathrm{C}$. The progress of the reaction was followed by TLC. After cooling to room temperature, the solid formed was filtered off, washed with ethanol, dried, and crystallized from DMF.

(Method 2) using conventional heating.

(Method 2a): A mixture of compounds 5a-e (10 mmol) and 6-aminothiouracil 6 (1.43 g, $10 \mathrm{mmol}$ ) was heated under reflux in DMF/or EtOH/TEA for several hours. The reaction mixture was allowed to cool to room temperature and the solid formed was filtered off, dried, and crystallized from DMF.

(Method 2b): A mixture of 2-cyanomethyl-1,3-benzothiazol 3 (1.74 g, $10 \mathrm{mmol}), 6$ amino thiouracil $\mathbf{6}(1.43 \mathrm{~g}, 10 \mathrm{mmol})$, and appropriate aldehydes $4 \mathbf{a}-\mathbf{e}(10 \mathrm{mmol})$ was heated under reflux in DMF for several hours. The reaction mixture was allowed to cool to room temperature and the solid formed was filtered off, dried, and crystallized from DMF.

7-amino-6-(1,3-benzothiazol-2-yl)-5-(thiophen-2-yl)-2-thioxo-2,3-dihydropyrido[2,3-d]pyrimidin-4(1H)-one (7a).

Brown powder, mp. $>300{ }^{\circ} \mathrm{C}$; IR $\left(\mathrm{KBr}, \mathrm{cm}^{-1}\right) ; 3379,3273\left(\mathrm{NH}_{2}, \mathrm{NH}\right), 3074(\mathrm{CH}$ aryl), $1680(\mathrm{C}=\mathrm{O}), 1599(\mathrm{C}=\mathrm{N}) ;{ }^{1} \mathrm{H}$ NMR (500 MHz, DMSO-d $\left., \delta, \mathrm{ppm}\right) ; 3.32-3.53$ (brs, 1H, NH, $\mathrm{D}_{2} \mathrm{O}$ exchangeable), 7.19-7.21(m, 2H, Ar- H), 7.23 (m, 1H, Ar- H), 7.44 (brs, 1H, Ar- H), 7.45 (brs, 1H, Ar-H), 7.46 (brs, 1H, Ar-H), 7.59 (brs, 1H, Ar-H), 8.10 (d, 1H, J = $7.45 \mathrm{~Hz}, \mathrm{Ar}-$ $H), 12.31$ (brs, $1 \mathrm{H}, \mathrm{NH}), 13.00$ (brs, $1 \mathrm{H}, \mathrm{NH})\left(\mathrm{NH}_{2}, 2 \mathrm{NH}, \mathrm{D}_{2} \mathrm{O}\right.$ exchangeable); ${ }^{13} \mathrm{C}-\mathrm{NMR}$ (125 MHz, DMSO- $d_{6}$ ) $\delta$ ppm: 108.10, 114.00, 115.20, 118.00, 129.00, 130.00, 131.10, 131.50, $132.10,135.80,142.10,149.20,150.00,156.80,159.80,160.00,162.00(\mathrm{C}=\mathrm{O}), 175.00(\mathrm{C}=\mathrm{S})$; Its MS (m/z), $409\left(\mathrm{M}^{+}, 74 \%\right) ; \mathrm{C}_{18} \mathrm{H}_{11} \mathrm{~N}_{5} \mathrm{OS}_{3}$ (409.5); Anal. Calcd.; \% C: 52.79, \% H: 2.71, \% N: 17.10; found \% C: $52.76, \% \mathrm{H}: 2.70, \% \mathrm{~N}: 17.08$.

7-amino-6-(1,3-benzothiazol-2-yl)-5-(5-methylfuran-2-yl)-2-thioxo-2,3-dihydropyrido[2,3-d] pyrimidin-4(1H)-one $(7 \mathbf{b})$.

Pale red powder, mp. > $300{ }^{\circ} \mathrm{C}$; IR $\left(\mathrm{KBr}, \mathrm{cm}^{-1}\right) ; 3400,3381\left(\mathrm{NH}_{2}, \mathrm{NH}\right), 3045(\mathrm{CH}$ aryl), 2938 (CH aliphatic), 1675 (C=O), 1608 (C=N); ${ }^{1} \mathrm{H}$ NMR (500 MHz, DMSO-d 6 , $\left.\delta, p p m\right)$; $2.85\left(\mathrm{~s}, 3 \mathrm{H}, \mathrm{CH}_{3}\right), 3.32$ (brs, 2H, $\left.\mathrm{NH}_{2}+\mathrm{H}_{2} \mathrm{O}\right), 7.20$ (d, 1H, J = 6.01 Hz, furan), 7.36-7.44 $(\mathrm{m}, 4 \mathrm{H}, \mathrm{Ar}-\mathrm{H}), 7.93(\mathrm{~d}, 1 \mathrm{H}, J=6.01 \mathrm{~Hz}$, furan), 12.33, 13.07 (2brs, $2 \mathrm{NH})\left(\mathrm{NH}_{2}, 2 \mathrm{NH}, \mathrm{D}_{2} \mathrm{O}\right.$ exchangeable); ${ }^{13} \mathrm{C}-\mathrm{NMR}\left(125 \mathrm{MHz}, \mathrm{DMSO}-d_{6}\right) \delta \mathrm{ppm}: 19.50,108.00,114.10,115.00,118.80$, 129.00, 130.00, 131.10, 131.40, 132.00, 135.80, 143.00, 149.20, 153.00, 156.80, 159.80, 162.00, $164.00(\mathrm{C}=\mathrm{O}), 176.00(\mathrm{C}=\mathrm{S})$; Its $\mathrm{MS}(\mathrm{m} / \mathrm{z}), 407\left(\mathrm{M}^{+}, 70 \%\right) ; \mathrm{C}_{19} \mathrm{H}_{13} \mathrm{~N}_{5} \mathrm{O}_{2} \mathrm{~S}_{2}$ (407.4); Anal. Calcd.; \% C: 56.01, \% H: 3.22, \% N: 17.19; found \% C: 56.00, \% H: 3.19, \% N: 17.17.

7-amino-6-(1,3-benzothiazol-2-yl)-5-(naphthalen-1-yl)-2-thioxo-2,3-dihydro pyrido[2,3-d] pyrimidin-4(1H)-one $(7 \mathrm{c})$.

Yellow powder, mp. $>300{ }^{\circ} \mathrm{C}$; IR $\left(\mathrm{KBr}, \mathrm{cm}^{-1}\right) ; 3373,3342\left(\mathrm{NH}_{2}, \mathrm{NH}\right), 3061(\mathrm{CH}$ aryl), 1678 (C=O), $1597(\mathrm{C}=\mathrm{N}) ;{ }^{1} \mathrm{H}$ NMR (500 MHz, DMSO-d $6, \delta$, ppm); 3.38 (brs, 2H, $\mathrm{NH}_{2}$ ), 7.29-7.93 (m, 11H, Ar-H), 11.88 (brs, 1H, NH), 12.76 (brs, 1H, NH) $\left(\mathrm{NH}_{2}, 2 \mathrm{NH}\right.$, 


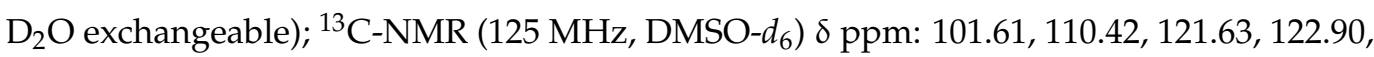
$125.50,126.04,126.39,126.65,126.96,127.46,128.20,129.00,132.00,133.90,135.40,135.90$, 152.06, 153.41, 158.16, 160.10, $164.00(\mathrm{C}=\mathrm{O}), 176.03(\mathrm{C}=\mathrm{S})$; Its MS (m/z), $453\left(\mathrm{M}^{+}, 66 \%\right)$; $\mathrm{C}_{24} \mathrm{H}_{15} \mathrm{~N}_{5} \mathrm{OS}_{2}$ (453.5); Anal. Calcd.; \% C: 63.56, \% H: 3.33, \% N: 15.44; found \% C: $63.53, \%$ $\mathrm{H}: 3.31, \% \mathrm{~N}: 15.40$

7-amino-6-(1,3-benzothiazol-2-yl)-5-(4-fluorophenyl)-2-thioxo-2,3-dihydropyrido[2,3-d] pyrimidin-4(1H)-one (7d).

Orange powder, mp. $>300{ }^{\circ} \mathrm{C}$; IR $\left(\mathrm{KBr}, \mathrm{cm}^{-1}\right)$; 3380, $3368\left(\mathrm{NH}_{2}, \mathrm{NH}\right), 3059(\mathrm{CH}$ aryl), $1680(\mathrm{C}=\mathrm{O}), 1600(\mathrm{C}=\mathrm{N}) ;{ }^{1} \mathrm{H}$ NMR $\left(500 \mathrm{MHz}, \mathrm{DMSO}-d_{6}, \delta, \mathrm{ppm}\right) ; 3.05\left(\mathrm{br}, 2 \mathrm{H}, \mathrm{NH}_{2}\right), 6.82(\mathrm{~d}$, $2 \mathrm{H}, J=7.9 \mathrm{~Hz}, \mathrm{Ar}-H,), 7.10-7.99(\mathrm{~m}, 4 \mathrm{H}, \mathrm{Ar}-H), 8.11$ (d, 2H, J = 8.1 Hz, Ar-H), 11.99, 12.69 (brs, $2 \mathrm{H}, 2 \mathrm{NH})\left(\mathrm{NH}_{2}, 2 \mathrm{NH}, \mathrm{D}_{2} \mathrm{O}\right.$ exchangeable); ${ }^{13} \mathrm{C}-\mathrm{NMR}\left(125 \mathrm{MHz}, \mathrm{DMSO}-\mathrm{d}_{6}\right) \delta \mathrm{ppm}$ : $112.33,115.51,121.97,122.67,122.91,123.16,125.90,126.70,127.34,131.88,131.95,133.41$, 148.24, 152.20, 153.57, 153.74, 158.60, 159.71, 164.20 (C=O), 175.99 (C=S); Its MS (m/z), 421 $\left(\mathrm{M}^{+}, 89 \%\right) ; \mathrm{C}_{20} \mathrm{H}_{12} \mathrm{FN}_{5} \mathrm{OS}_{2}$ (421.4); Anal. Calcd.; \% C: $56.99, \% \mathrm{H}: 2.87, \% \mathrm{~N}: 16.62$; found \% C: $56.97, \% \mathrm{H}: 2.84, \% \mathrm{~N}: 16.60$.

7-amino-5-(piperon-2-yl)-6-(1,3-benzothiazol-2-yl)-2-thioxo-2,3-dihydropyrido[2,3-d]pyrimidin-4(1H)-one (7e).

Pale yellow powder, mp. $>300{ }^{\circ} \mathrm{C}$; IR $\left(\mathrm{KBr}, \mathrm{cm}^{-1}\right) ; 3370,3278\left(\mathrm{NH}_{2}, \mathrm{NH}\right), 3040(\mathrm{CH}$ aryl), 2924 (CH aliphatic), $1678(\mathrm{C}=\mathrm{O}), 1608(\mathrm{C}=\mathrm{N}) ;{ }^{1} \mathrm{H}$ NMR (500 MHz, DMSO- $\left.d_{6}, \delta, \mathrm{ppm}\right)$; $6.08\left(\mathrm{~s}, 2 \mathrm{H}, \mathrm{O}-\mathrm{CH}_{2}-\mathrm{O}\right), 6.90(\mathrm{~d}, 1 \mathrm{H}, J=6.9 \mathrm{~Hz}, \mathrm{Ar}-\mathrm{H}), 7.41-7.45$ (m, 2H, Ar-H), $7.50-7.51$ (m, $1 \mathrm{H}, \mathrm{Ar}-H), 7.73$ (s, 1H, Ar-H), $7.88(\mathrm{~d}, 1 \mathrm{H}, J=6.9 \mathrm{~Hz}, \mathrm{Ar}-H), 8.05(\mathrm{~d}, 1 \mathrm{H}, J=7.01 \mathrm{~Hz}, \mathrm{Ar}-H)$, $8.12,9.63$ and 9.73 (brs, $4 \mathrm{H}, \mathrm{NH}_{2}$ and $\left.2 \mathrm{NH}\right),\left(\mathrm{NH}_{2}, 2 \mathrm{NH}, \mathrm{D}_{2} \mathrm{O}\right.$ exchangeable); ${ }^{13} \mathrm{C}-\mathrm{NMR}$ (125 MHz, DMSO-d 6 ) $\delta$ ppm: $102.10\left(\mathrm{O}-\mathrm{CH}_{2}-\mathrm{O}\right), 108.00,115.00,118.20,123.00,128.00$, $130.00,132.10,136.00,142.00,133.41,153.00,153.20,156.40,158.00,162.00,165.00,166.00$ $(\mathrm{C}=\mathrm{O}), 175.99(\mathrm{C}=\mathrm{S})$; Its MS (m/z), $446\left(\mathrm{M}^{+}, 71 \%\right) ; \mathrm{C}_{21} \mathrm{H}_{13} \mathrm{~N}_{5} \mathrm{O}_{3} \mathrm{~S}_{2}$ (447.4); Anal. Calcd.; \% C: $56.36, \% \mathrm{H}: 2.93, \% \mathrm{~N}: 15.65$; found \% C: $56.33, \% \mathrm{H}: 2.92, \% \mathrm{~N}: 15.64$.

1-amino-2-(aryl)pyrrolo[2,1-b][1,3]benzothiazole-3-carbonitrile (9a-e).

General procedure: (Method 1) under microwave irradiation.

(Method 1a): A mixture of 2-cyanomethyl-1,3-benzothiazol 3 (0.87 g, $5 \mathrm{mmol})$, benzoyl cyanide 8 (0.65 g, $5 \mathrm{mmol})$ and appropriate aldehyde $4 \mathbf{a}-\mathbf{e}(5 \mathrm{mmol})$ in EtOH/DBU was placed in a microwave process vial. The vial was closed and subjected to microwave irradiation for $25 \mathrm{~min}$ at $120^{\circ} \mathrm{C}$. Cooling the mixture to room temperature the solid precipitate was collected by filtration, dried and crystallized from dioxane.

(Method 1b): A mixture of compounds 5a-e and benzoyl cyanide 8 in EtOH/DBU was placed in a microwave process vial. The vial was closed and subjected to microwave irradiation for (20-25) $\mathrm{min}$ at $120^{\circ} \mathrm{C}$. Cooling the mixture to room temperature, the solid precipitate was collected by filtration, dried and crystallized from dioxane.

(Method 2) using conventional heating.

(Method 2a): A mixture of 2-cyanomethyl-1,3-benzothiazol 3 (5 mmol), benzoyl cyanide 8 (5 mmol) and appropriate aldehyde $4 \mathbf{a}-\mathbf{e}$ was heated under reflux in ethanol and trimethylamine for an appropriate time. The reaction mixture was allowed to cool to room temperature and the solid formed was filtered off, dried and crystallized from dioxane.

(Method 2b): A mixture of compounds $5 \mathbf{a}-\mathbf{e}(5 \mathrm{mmol})$ and benzoyl cyanide 8 ( $5 \mathrm{mmol})$ was heated under reflux in ethanol and trimethylamine for an appropriate time. The reaction mixture was allowed to cool to room temperature and the solid formed was filtered off, dried and crystallized from dioxane.

1-amino-2-(thiophen-2-yl)pyrrolo[2,1-b][1,3]benzothiazole-3-carbonitrile (9a).

Deep yellow powder, mp. $255-257^{\circ} \mathrm{C}$; IR $\left(\mathrm{KBr}, \mathrm{cm}^{-1}\right) ; 3420,3412\left(\mathrm{NH}_{2}\right), 3068(\mathrm{CH}$ aryl), 2249 (CN); ${ }^{1} \mathrm{H}$ NMR (500 MHz, DMSO- $\left.d_{6}, \delta, \mathrm{ppm}\right) ; 7.19$ (s, 1H, Ar-H), 7.38-7.69 (m, 2H, Ar-H), 7.78-7.85 (m, 2H, Ar-H), 7.87 (m, 1H, Ar-H), 8.02 (m, 1H, Ar-H), 8.34 (brs, NH, $\mathrm{D}_{2} \mathrm{O}$ exchangeable); ${ }^{13} \mathrm{C}-\mathrm{NMR}\left(125 \mathrm{MHz}, \mathrm{DMSO}-d_{6}\right) \delta$ ppm: $102.20(\mathrm{CN}), 121.74,123.43$, 
$125.88,127.00,128.57,133.35,135.08,135.53,136.97,138.83,153.74,162.38$. Its MS (m/z), 295 $\left(\mathrm{M}^{+}, 90 \%\right) ; \mathrm{C}_{15} \mathrm{H}_{9} \mathrm{~N}_{3} \mathrm{~S}_{2}$ (295.3); Anal. Calcd.; \% C: 60.99, \% H: 3.07, \% N: 14.23; found \% C: 60.97, \% H: 3.07, \% N: 14.21 .

1-amino-2-(5-methylfuran-2-yl)pyrrolo[2,1-b][1,3]benzothiazole-3-carbonitrile (9b).

Brown powder, mp. 232-234 ${ }^{\circ} \mathrm{C}$; IR $\left(\mathrm{KBr}, \mathrm{cm}^{-1}\right)$; 3415, $3409\left(\mathrm{NH}_{2}\right), 3090(\mathrm{CH}$ aryl), $2233(\mathrm{CN}) ;{ }^{1} \mathrm{H}$ NMR (500 MHz, DMSO-d $\left.6, \delta, \mathrm{ppm}\right) ; 2.85$ (s, 3H, $\left.\mathrm{CH}_{3}\right), 7.20(\mathrm{~d}, 1 \mathrm{H}, J=$ $5.9 \mathrm{~Hz}$, furan), $7.22-7.44(\mathrm{~m}, 4 \mathrm{H}, \mathrm{Ar}-\mathrm{H}), 7.93\left(\mathrm{~d}, 1 \mathrm{H}, J=5.9 \mathrm{~Hz}\right.$, furan), $12.33\left(\mathrm{~d}, \mathrm{NH}, \mathrm{D}_{2} \mathrm{O}\right.$ exchangeable); ${ }^{13} \mathrm{C}-\mathrm{NMR}\left(125 \mathrm{MHz}, \mathrm{DMSO}-d_{6}\right) \delta$ ppm: $22.50\left(\mathrm{CH}_{3}\right), 92.32(\mathrm{CN}), 100.00$, 102.99, 115.84, 128.36, 130.03, 133.57, 136.77, 158.67, 159.08, 159.44, 161.71. Its MS (m/z), 293 $\left(\mathrm{M}^{+}, 94 \%\right) ; \mathrm{C}_{16} \mathrm{H}_{11} \mathrm{~N}_{3} \mathrm{OS}$ (293.3); Anal. Calcd.; \% C: 65.51, \% H: 3.78, \% N: 14.32; found \% C: $65.50, \%$ H: $3.76, \%$ N: 14.29 .

1-amino-2-(naphthalen-1-yl)pyrrolo[2,1-b][1,3]benzothiazole-3-carbonitrile (9c).

Pale red powder, mp. 260-262 ${ }^{\circ} \mathrm{C}$; IR (KBr, cm $\left.{ }^{-1}\right)$; 3430, $3411\left(\mathrm{NH}_{2}\right), 3100(\mathrm{CH}$ aryl), 2235(CN); ${ }^{1} \mathrm{H}$ NMR (500 MHz, DMSO-d $\left.6, \delta, p p m\right) ; 7.45-7.58$ (m, 5H, Ar-H), 7.91 (m, 2H, Ar-H), 7.99 (m, 2H, Ar-H), $8.12(\mathrm{~m}, 1 \mathrm{H}, \mathrm{Ar}-\mathrm{H}) 8.30$ (m, 1H, Ar- H), 9.03 (brs, NH, D $\mathrm{O}$ exchangeable); ${ }^{13} \mathrm{C}-\mathrm{NMR}\left(125 \mathrm{MHz}\right.$, DMSO- $\left.d_{6}\right) \delta$ ppm: 109.00 (CN), 121.83, 123.26, 123.88, $125.61,126.23,126.84,127.10,127.66,127.82,129.22,129.52,132.55,144.78,153.75,162.45$. Its MS (m/z), $339\left(\mathrm{M}^{+}, 81 \%\right) ; \mathrm{C}_{21} \mathrm{H}_{13} \mathrm{~N}_{3} \mathrm{~S}$ (339.4); Anal. Calcd.; \% C: 74.31, \% H: 3.86, \% N: 12.38; found \% C: $74.30, \% \mathrm{H}: 3.84, \% \mathrm{~N}: 12.36$.

1-amino-2-(4-fluorophenyl)pyrrolo[2,1-b][1,3]benzothiazole-3-carbonitrile (9d).

Yellow powder, mp. 269-270 ${ }^{\circ} \mathrm{C}$; IR $\left(\mathrm{KBr}, \mathrm{cm}^{-1}\right)$; 3439, $3418\left(\mathrm{NH}_{2}\right), 3098(\mathrm{CH}$ aryl), $2250(\mathrm{CN}) ;{ }^{1} \mathrm{H}$ NMR (500 MHz, DMSO- $\left.d_{6}, \delta, \mathrm{ppm}\right) ; 7.25(\mathrm{~d}, 2 \mathrm{H}, \mathrm{Ar}-H, J=8.00), 7.40-7.62(\mathrm{~m}$, $2 \mathrm{H}, \mathrm{Ar}-H), 7.85$ (d, 2H, J = 7.98, Ar-H), $8.00-8.15$ (m, 2H, Ar-H), 9.49 (brs, 2H, $\mathrm{NH}_{2}, \mathrm{D}_{2} \mathrm{O}$ exchangeable); ${ }^{13} \mathrm{C}-\mathrm{NMR}\left(125 \mathrm{MHz}, \mathrm{DMSO}-d_{6}\right) \delta$ ppm: $90.54(\mathrm{CN}), 115.65,121.83,128.33$, $130,16,133.84,135.74,141.12,141.58,144.78,154.77,157.98,158.09,161.35$. Its MS (m/z), 307 $\left(\mathrm{M}^{+}, 88 \%\right) ; \mathrm{C}_{17} \mathrm{H}_{10} \mathrm{FN}_{3} \mathrm{~S}$ (307.3); Anal. Calcd.; \% C: $66.43, \% \mathrm{H}: 3.28, \% \mathrm{~N}: 13.67$; found \% C: $66.40, \% \mathrm{H}: 3.26, \% \mathrm{~N}: 13.66$.

1-amino-2-(piperon-2-yl)pyrrolo[2,1-b][1,3]benzothiazole-3-carbonitrile (9e).

White powder, mp. 248-250 ${ }^{\circ} \mathrm{C}$; IR $\left(\mathrm{KBr}, \mathrm{cm}^{-1}\right) ; 3429,3409\left(\mathrm{NH}_{2}\right), 3080(\mathrm{CH}$ aryl $)$, 2985, 2868 (CH aliphatic), 2253(CN); ${ }^{1} \mathrm{H}$ NMR (500 MHz, DMSO- $\left.d_{6}, \delta, p p m\right) ; 6.08$ (s, 2H, $\left.\mathrm{O}-\mathrm{CH}_{2}-\mathrm{O}\right), 7.41-7.51$ (m, 3H, Ar-H), 7.73 (s, 1H, Ar-H), 7.88-7.89 (m, 1H, Ar-H), 8.04-8.12 (m, 2H, Ar- H), 9.42 (brs, 2H, $\mathrm{NH}_{2}, \mathrm{D}_{2} \mathrm{O}$ exchangeable); ${ }^{13} \mathrm{C}-\mathrm{NMR}$ (125 MHz, DMSO-d 6 ) $\delta$ ppm: 92.32 (CN), 102.99, 115.84, 128.36, 130.03, 133.57, 136.77, 158.67, 159.08, 159.44, 161.71, 162.00, 162.89. Its MS (m/z), $333\left(\mathrm{M}^{+}, 92 \%\right) ; \mathrm{C}_{18} \mathrm{H}_{11} \mathrm{~N}_{3} \mathrm{O}_{2} \mathrm{~S}$ (333.3); Anal. Calcd.; \% C: 64.85, $\% \mathrm{H}: 3.33, \% \mathrm{~N}: 12.60$; found \% C: $64.83, \% \mathrm{H}: 3.30, \% \mathrm{~N}: 12.58$.

\subsection{Biological Evaluation}

3.3.1. Antimicrobial Activity

The antimicrobial activity of the series of newly synthesized compounds $5 \mathbf{a}-\mathbf{e}, \mathbf{7 a}-\mathbf{e}$ and 9a-e was evaluated in vitro against three Gram-positive bacteria Staphylococcus aureus ATCC-23444, Streptococcus pneumonia ATCC 22038 and Bacillus subtilis ATCC 24431, three Gram-negative bacteria Chlamydia pneumoniae ATCC-26452, Escherichia coli MTCC 23489, and Salmonella typhi ATCC 24351 as well as three fungi Aspergillus flavus (ATCC-24866, Candida albicans ATCC 24328 and Ganoderma lucidum ATCC-46816. All microorganisms were purchased from the American Type Culture Collection (Manassas, VA, USA). Using agar disk diffusion technique [41], using cefotaxime $\left(109.8 \mu \mathrm{mol} \mathrm{L}{ }^{-1}\right)$ and fluconazole $\left(15.313 \mu \mathrm{mol} \mathrm{L}{ }^{-1}\right)$ as reference drugs for antibacterial and antifungal activity, respectively. A solution of $100 \mu \mathrm{g} \mathrm{mL} \mathrm{m}^{-1}$ of the test compound was applied to microplate-wells, $1 \mathrm{~cm}$ in diameter. Inhibition zones were measured with calipers or automated scanners after $24 \mathrm{~h}$ incubation at $37^{\circ} \mathrm{C}$ and compared with the standard. Minimum inhibitory concentration $\left(\right.$ MIC $\left.\mu \mathrm{mol} \mathrm{L}{ }^{-1}\right)$, of all synthesized compounds was carried out by using serial plate dilution 
technique [42]. Serial dilutions were prepared from the stock solution by dissolving $5 \mathrm{mg}$ of each test compound in $1 \mathrm{~mL}$ of DMSO. The plates were incubated at $37^{\circ} \mathrm{C}$ for $24 \mathrm{~h}$. DMSO was used as a solvent control which had no effect on bacterial growth. Results of antimicrobial activities are summarized in Tables 6 and 7.

\subsubsection{Antitumor Activity}

Human carcinoma cell lines (lung cell NCI-H460, liver cancer HepG2 and colon cancer HCT-116) were provided by the National Cancer Institute (NCI, Cairo, Egypt). (FBS) fetal bovine serum from Gibco Invitrogen Co. (UK). Dimethyl sulfoxide (DMSO) and doxorubicin were from Sigma Chemical Co. (USA).

In Vitro Anticancer Activity by MTT Assay

Cell culture: All the synthesized compounds were tested in vitro for anticancer activity against three tumor cell lines (lung cell NCI-H460, liver cancer HepG2 and colon cancer HCT-116). Cells were cultured in humidified atmosphere at $37^{\circ} \mathrm{C}$ with $5 \% \mathrm{CO}_{2}$. The cell density was $2 \times 10^{3}$ seeded in a 96-multiwell plate in $0.1 \mathrm{~mL}$ DMEM (Dulbecco's Modified Eagle's Medium) supplemented with 10\% (FBS) fetal bovine serum for $24 \mathrm{~h}$. The tested compounds were dissolved in DMSO as a stock solution $\left(0.1 \mathrm{~mol} \mathrm{~L}^{-1}\right)$. After $48 \mathrm{~h}$ of incubation, cells were treated with different concentrations of the tested compounds $(5$, 12 , 25, and $50 \mu \mathrm{mol} \mathrm{L}{ }^{-1}$ ). The medium cells of the control group contained $0.2 \%$ DMSO. For each individual dose triplicate wells were performed. To each well, MTT in phosphate buffered saline (PBS, $5 \mathrm{mg} / \mathrm{mL}$ ) was added and incubated for $4 \mathrm{~h}$ at $37^{\circ} \mathrm{C}$. After that, MTT reagent was removed and added (DMSO, $100 \mu \mathrm{L}$ ) to each well to dissolve formazan crystals. A measure of $100 \mu \mathrm{M}$ of Doxorubicin was used as a standard drug and the optical density was determined at $570 \mathrm{~nm}$ with a DTX 880 multimode detector. The calculation of the IC50 was done by performing 4 concentrations of the compounds on the cells in triplicate and the results were analyzed using SPSS software (Version 20.0).

\subsubsection{Antioxidant $\mathrm{ABTS}^{\bullet+}$ Radical Activity}

The ABTS ${ }^{\bullet+}$ isolation activity was described by Dorman and Hiltunen [43]. A sample ( $2 \mathrm{mM}$ ) of ABTS (3-ethylbenzthiazoline-6-sulfonic acid) was treated with potassium persulfate $(2.45 \mathrm{mM})$ to produce $\mathrm{ABTS}^{\bullet+}$ solution and then incubated in dark room at room temperature for $16 \mathrm{~h}$. The absorbance $\left(A_{0}\right)$ of the resulting green-blue solution (ABTS ${ }^{\bullet+}$ ) was adjusted before use at $0.7 \pm 0.05 \mathrm{~nm}$ at $\lambda 734 \mathrm{~nm}$. The solution of $(50 \mu \mathrm{L}$ of $2 \mathrm{mM})$ of the tested compounds in spectroscopic grade $\mathrm{MeOH} /$ phosphate buffer (1:1) was treated with $\mathrm{ABTS}^{\bullet+}$. Afterwards, the absorbance $\left(A_{1}\right)$ was measured, then the $\%$ inhibition was calculated as

$$
\text { ABTS }^{\bullet+} \text { scavenging effect } \%=\left[\left(\mathrm{A}_{0}-\mathrm{A}_{1}\right) \backslash \mathrm{A}_{1}\right] \times 100
$$

Trolox was used as standard antioxidant (positive control). The results (IC50 value) were calculated.

\subsubsection{Bleomycin-Dependent DNA Damage}

Assay mixtures [44] contained DNA $(0.5 \mathrm{mg} / \mathrm{mL})$, bleomycin sulfate $(0.05 \mathrm{mg} / \mathrm{mL})$, $\mathrm{FeCl}_{3}(50 \mathrm{mM}), \mathrm{MgCl}_{2}(5 \mathrm{mM})$, and selected synthesized compounds to be examined at different concentrations. To start the reaction, Trolox was added which was used as positive control and was incubated at $37^{\circ} \mathrm{C}$ for $1 \mathrm{~h}$. After the incubation period, $0.05 \mathrm{~mL}$ of EDTA $(0.1 \mathrm{M})$ was added to terminate the reaction. the addition of $0.5 \mathrm{~mL}$ of (TBA) thiobarbituric acid $(1 \%, w / v)$ and $0.5 \mathrm{~mL} \mathrm{HCI}(25 \%, v / v)$ then heated in the water bath for $10 \mathrm{~min}$ at $80{ }^{\circ} \mathrm{C}$ to assay DNA damage. the extent of DNA damage was measured after centrifugation, by the increase in absorbance at $532 \mathrm{~nm}$.

\section{Conclusions}

The present investigation offers effective and rapid new procedures for the synthesis of the newly polycondensed heterocyclic ring systems. All the newly synthesized com- 
pounds showed antimicrobial activity against bacteria and fungi. Among the synthesized compounds, compounds $\mathbf{7 a}, \mathbf{d}$, and $\mathbf{9 a}, \mathbf{d}$ showed more potent inhibitory activities than cefotaxime and fluconazole while the remaining compounds exhibited good to moderate activity against bacteria and fungi. Compounds $\mathbf{7 a}, \mathbf{d}$, and $\mathbf{9 a}, \mathbf{d}$ also exhibited higher cytotoxicity for all tested cell lines compared to doxorubicin. These derivatives exhibited higher antioxidant activity compared to Trolox, also manifested the best protective effect against DNA damage induced by Bleomycin. Based on the anticancer and antioxidant activity, we can consider 2,3-dihydropyrido[2,3-d]pyrimidine-4-one and pyrrolo[2,1-b][1,3]benzothiazole as highly potential molecules for the development of novel anticancer drugs.

Supplementary Materials: The following are available online. Figure S1. ${ }^{1} \mathrm{H}-\mathrm{NMR}$ and ${ }^{13} \mathrm{C}-\mathrm{NMR}$ spectra for all compounds.

Author Contributions: Conceptualization, H.N.H. and A.-R.B.A.E.-G.; methodology, H.N.H. and A.-R.B.A.E.-G.; validation, H.N.H.; A.-R.B.A.E.-G.; A.A.A.-M. and M.Y.A.M.; formal analysis, H.N.H.; A.-R.B.A.E.-G.; A.A.A.-M. and M.Y.A.M.; investigation, H.N.H. and A.-R.B.A.E.-G.; data curation, H.N.H.; A.-R.B.A.E.-G. and A.A.A.-M.; writing-original draft preparation, H.N.H. writing-review and editing, H.N.H. and A.-R.B.A.E.-G.; visualization and supervision, H.N.H. and A.-R.B.A.E.-G.; All authors have read and agreed to the published version of the manuscript.

Funding: This research received no external funding.

Informed Consent Statement: Not applicable.

Data Availability Statement: The data presented in this study are available.

Acknowledgments: This research was supported by the Deanship of Scientific Research, Imam Mohammad Ibn Saud Islamic University, Saudi Arabia, Grant No. (20-13-12-027). The authors are grateful to the Micro-Analytical Unit, National Research center, Cairo, Egypt, for micro-analytical data, IR, NMR and mass spectra. The authors also are grateful to the staff of the Bacteriology and pharmacology Laboratory, National Research Center (Cairo, Egypt). We also thank the antitumor Evaluation Branch of the National Cancer Institute (Cairo, Egypt) for performing biological evaluations.

Conflicts of Interest: The authors declare no conflict of interest.

Sample Availability: Samples of the compounds are not available from authors.

\section{References}

1. El-Gazzar, A.B.A.; Hafez, H.N. Synthesis of new 4-substituted pyrido[2,3-d]pyrimidin-4(1H)-ones and their evaluation for anti-inflammatory and analgesic activities. Bioorg. Med. Chem. Lett. 2009, 19, 3392-3397. [CrossRef] [PubMed]

2. Dasari, S.R.; Tondepu, S.; Vadali, L.R.; Seelam, N. PEG-400 mediated an efficient eco-friendly synthesis of new isoxazolyl pyrido[2,3-d]pyrimidines and their anti-inflammatory and analgesic activity. Synth. Commun. 2020, 50, 2950-2961. [CrossRef]

3. Rani, N.V.; Kunta, R. PEG-400 promoted a simple, efficient and eco-friendly synthesis of functionalized novel isoxazolyl pyrido[2,3-d] pyrimidines and their antimicrobial and anti-inflammatory activity. Synth. Commun. 2021, 51, 1171-1183. [CrossRef]

4. Rajesh, S.M.; Kumar, R.S.; Libertsen, L.A.; Perumal, S.; Yogeeswari, P.; Sriram, D. A green expedient synthesis of pyridopyrimidine2-thiones and their antitubercular activity. Bioorg. Med. Chem. Lett. 2011, 21, 3012-3016. [CrossRef] [PubMed]

5. Ibrahim, M.A.; Al-Harbi, S.A.; Allehyani, E.S. Construction, characterization, and antimicrobial evaluation of the novel heteroannulated chromeno $\left[2^{\prime \prime}, 3^{\prime \prime}: 6^{\prime}, 5^{\prime}\right]$ pyrido $\left[2^{\prime}, 3^{\prime}\right.$-d] $[1,3]$ thiazolo[3,2-a]pyrimidines. J. Heterocycl. Chem. 2021, 58, 241-249. [CrossRef]

6. Abdelhameed, R.M.; Darwesh, O.M.; El-Shahat, M. Synthesis of arylidene hydrazinyl pyrido [2,3-d] pyrimidin -4- ones as potent anti-microbial agents. Heliyon 2020, 6, e04956. [CrossRef] [PubMed]

7. Elsaedanya, S.K.; Zeinb, M.A.; AbdElRehimb, E.M.; Keshk, R.M. Synthesis and Biological Activity Studies of Novel Pyrido[2,3d]pyrimidines and Pyrido[2,3-d] triazines. Russ. J. Bioorg. Chem. 2021, 47, 552-560. [CrossRef]

8. Huang, M.; Huang, Y.; Guo, J.; Yu, L.; Chang, Y.; Wang, X.; Luo, J.; Huang, Y.; Tu, Z.; Lu, X.; et al. Pyrido[2,3-d]pyrimidin-7(8H)ones as new selective orally bioavailable Threonine Tyrosine Kinase (TTK) inhibitors. Eur. J. Med. Chem. 2021, $211,113023$. [CrossRef] [PubMed]

9. Zheng, Z.G.; Mao, Y.; Lee, H.C.; Pratt, J.K.; Koenig, J.R.; Perner, R.J.; Cowart, M.D.; Gfesser, G.A.; Steve, M.; Chu, K.L.; et al. Adenosine kinase inhibitors: Polar 7-Substitutent of Pyridopyrimidine derivatives improving their locomotor selectivity. Bioorg. Med. Chem. Lett. 2003, 13, 3041-3044. [CrossRef] 
10. DeGoey, D.A.; Betebenner, D.A.; Grampovnik, D.J.; Liu, D.; Pratt, J.K.; Tufano, M.D.; He, W.; Krishnan, P.; Pilot-Matias, T.J.; Marsh, K.C.; et al. Discovery of pyrido[2,3-d]pyrimidine-based inhibitors of HCV NS5A. Bioorg. Med. Chem. lett. 2013, 23, 3627-3630. [CrossRef] [PubMed]

11. Gouda, M.A.S.; Salem, M.A.I.; Mahmoud, N.F.H. 3D-pharmacophore study molecular docking and synthesis of pyrido[2,3d]pyrimidine-4(1H) dione derivatives with in vitro potential anticancer and antioxidant activities. J. Heterocycl. Chem. 2020, 57, 3988-4006. [CrossRef]

12. Khajouei, M.R.; Khodarahmi, G.; Ghaderi, A. Synthesis and cytotoxic evaluation of some novel 3-[2-(2-phenyl-thiazol-4-yl)-ethyl]3H-pyrido[2,3-d]pyrimidin-4-one derivatives. Res. Pharm Sci. 2021, 16, 455-463.

13. Dangolani, S.K.; Panahi, F.; Tavaf, Z.; Nourisefat, M.; Yousefi, R.; Khalafi-Nezhad, A. Synthesis and Antioxidant Activity Evaluation of Some Novel Aminocarbonitrile Derivatives Incorporating Carbohydrate Moieties. ACS Omega 2018, 3, 10341-10350. [CrossRef] [PubMed]

14. Medjdoub, A.; Belhadj, F.; Merzouk, A.S.; Hamed, Y.B.; Kibou, Z.; Braham, N.C.; Merzouk, H. In vitro peripheral blood mononuclear cell proliferation, cytokine secretion and oxidative stress modulation by pyrido[2,3-d] pyrimidines. Chem. Pap. 2020, 74, 903-913. [CrossRef]

15. Gangjee, A.; Adaira, O.; Queenerb, S.F. Synthesis of 2,4-Diamino-6-(thioarylmethyl) pyrido [2,3-d]pyrimidines as Dihydrofolate Reductase Inhibitors. Bioorg. Med. Chem. 2001, 9, 2929-2935. [CrossRef]

16. Wang, M.; Yang, J.; Yuan, M.; Xue, L.; Li, H.; Tian, C.; Wang, X.; Liu, J.; Zhang, Z. synthesis and antiproliferative activity of a series of novel 6-substituted pyrido[3,2-d]pyrimidines as potential nonclassical lipophilic antifolates targeting dihydrofolate reductase. Eur. J. Med. Chem. 2017, 10, 88-97. [CrossRef] [PubMed]

17. Panahi, F.; Yousefi, R.; Mehraban, M.H.; Khalafi-Nezhad, A. Synthesis of new pyrimidine-fused derivatives as potent and selective antidiabetic $\alpha$-glucosidase inhibitors. Carbohydr. Res. 2013, 380, 81-91. [CrossRef] [PubMed]

18. Adib, M.; Peytam, F.; Rahmanian-Jazi, M.; Mahernia, S.; Larijani, B. New 6-amino- pyrido[2,3-d] pyrimidine -2,4-diones as novel agents to treat type 2 diabetes:A simple and efficient synthesis, $\alpha$-glucosidase inhibition, molecular modeling and kinetic study. Eur. J. Med. Chem. 2018, 155, 353-363. [CrossRef]

19. Maus, H.; Barthels, F.; Hammerschmidt, S.J.; Kopp, K.; Millies, B.; Gellert, A.; Ruggieri, A.; Schirmeister, T. SAR of novel benzothiazoles targeting an allosteric pocket of DENV and ZIKV NS2B/NS3 proteases. Bioorg. Chem. 2021, 47, 116392. [CrossRef] [PubMed]

20. Dhameliya, T.M.; Tiwari, R.; Banerjee, A.; Pancholia, S.; Chakraborti, A.K. Benzo[d]thiazole-2-carbanilides as new anti-TB chemotypes: Design, synthesis, biological evaluation, and structure-activity relationship. Eur. J. Med. Chem. 2018, 155, 364-380. [CrossRef]

21. Aly, M.W.; Ludwig, F.-A.; Deuther-Conrad, W.; Brust, P.; Abadi, A.H.; Moldovan, R.-P.; Osman, N.A. Development of fluorinated and methoxylated benzothiazole derivatives as highly potent and selective cannabinoid CB2 receptor ligands. Bioorg. Chem. 2021, 114, 105191. [CrossRef] [PubMed]

22. Wang, Z.; Shi, X.; Wang, J. Synthesis, structure-activity relationships and preliminary antitumor evaluation of benzothiazole-2-thiol derivatives as novel apoptosis inducers. Bioorg. Med. Chem. Lett. 2011, 21, 1097-1101. [CrossRef] [PubMed]

23. Tokala, R.; Mahajan, S.; Kiranmai, G.; Sigalaplli, D.K.; Stephy, S.S.; John, E.; Nagesh, N.; Shankaraiah, N. Development of $\beta$ carboline-benzothiazole hybrids via carboxamide formation as cytotoxic agents: DNA intercalative topoisomerase II $\alpha$ inhibition and apoptosis induction. Bioorg. Chem. 2021, 106, 104481. [CrossRef] [PubMed]

24. Almehmadi, M.A.; Aljuhani, A.; Alraqa, S.Y.; Ali, I.; Rezki, N.; Aouad, M.R.; Hagar, M. Design, synthesis, DNA binding, modeling, anticancer studies and DFT calculations of Schiff bases tethering benzothiazole-1,2,3-triazole conjugates. J. Mol. Struct. 2021, 1225, 129148. [CrossRef]

25. Catalano, A.; Rosato, A.; Salvagno, L.; Iacopetta, D.; Ceramella, J.; Fracchiolla, G.; Sinicropi, M.S.; Franchini, C. BenzothiazoleContaining Analogues of Triclocarban with Potent Antibacterial Activity. Antibiotics 2021, 10, 803. [CrossRef] [PubMed]

26. Alkhafaji, M.N.A.M.; Aljamali, D.N.M. Preparation of Benzothiazole-Formazane Reagents and Studying of (Spectral, Thermal, Scanning Microscopy, Biological Evaluation). Int. J. Pharm. Res. 2021, 13, 4290-4300.

27. Sahu, P.K.; Sahu, P.K.; Lal, J.; Thavaselvam, D.; Agarwal, D. A facile green synthesis and in vitro antimicrobial activity $4 \mathrm{H}$ pyrimido[2,1-b][1,3] benzothiazole derivatives using aluminum trichloride under solvent free conditions. Med. Chem. Res. 2012, 21, 3826-3834. [CrossRef]

28. Amir, M.; Asif, S.; Ali, I.; Hassan, M.Z. synthesis of benzothiazole derivatives having acetamido and carbothioamido pharmacophore as anticonvulsant agents. Med. Chem. Res. 2012, 21, 2661-2670. [CrossRef]

29. Nguyen, W.; Lee, E.F.; Evangelista, M.; Lee, M.; Harris, T.J.; Colman, P.M.; Smith, N.A.; Williams, L.B.; Jarman, K.E.; Lowes, K.N.; et al. Optimization of Benzothiazole and Thiazole Hydrazones as Inhibitors of Schistosome BCL-2. ACS Infect. Dis. 2021, 7, 1143-1163. [CrossRef]

30. Patil, V.S.; Nandre, K.P.; Ghosh, S.; Rao, V.J.; Chopade, B.A.; Sridhar, B.; Bhosale, S.V.; Bhosale, S.V. Synthesis, crystal structure and antidiabetic activity of substituted (E)-3-(Benzo [d]thiazol-2-ylamino) phenylprop-2-en-1-one. Eur. J. Med. Chem. 2013, 59, 304-309. [CrossRef] [PubMed]

31. Prakash, S.; Somiya, G.; Elavarasan, N.; Subashini, K.; Kanaga, S.; Dhandapani, R.; Sivanandam, M.; Kumaradhas, P.; Thirunavukkarasu, C.; Sujatha, V. Synthesis and characterization of novel bioactive azo compounds fused with benzothiazole and their versatile biological applications. J. Mol. Struct. 2021, 1224, 129016. [CrossRef] 
32. Nepovimova, E.; Svobodova, L.; Dolezal, R.; Hepnarova, V.; Junova, L.; Jun, D.; Korabecny, J.; Kucera, T.; Gazova, Z.; Motykova, K.; et al. Tacrine-Benzothiazoles: Novel class of potential multitarget anti-Alzheimeŕs drugs dealing with cholinergic, amyloid and mitochondrial systems. Bioorg. Chem. 2021, 107, 104596. [CrossRef]

33. Özil, M.; Tuzcuoğlu, Ö.; Emirik, M.; Baltaş, N. Developing a scaffold for urease inhibition based on benzothiazoles: Synthesis, docking analysis, and therapeutic potential. Arch. Pharm. 2021, 354, e2100200. [CrossRef] [PubMed]

34. Kamal, Ä.; Ashraf, M.; Vishnu Vardhan, M.V.P.S.; Faazil, S.; Lakshma Nayak, V. Synthesis and anticancer potential of benzothiazole linked phenylpyridopyrimidinones and their diones as mitochondrial apoptotic inducers. Bioorg. Med. Chem. lett. 2014, 24 , 147-151. [CrossRef] [PubMed]

35. Shi, F.; Ding, J.; Zhang, S.; Hao, W.-J.; Cheng, C.; Tu, S. Substrate-controlled chemoselective synthesis and potent cytotoxic activity of novel 5,6,7-triarylpyrido[2,3-d]pyrimidin-4-one derivatives. Bioorg. Med. Chem. lett. 2011, 21, 1554-1558. [CrossRef]

36. Kumbhare, M.R.; Kumar, V.K.; Ramaiah, J.M. Synthesis and biological evaluation of novel Mannich bases of 2-arylimidazo[2,1b]benzothiazoles as potential anti-cancer agents. Eur. J. Med. Chem. 2011, 46, 4258-4266. [CrossRef] [PubMed]

37. El-Gazzar, A.B.A.; Hafez, H.N.; Zaki, M.E.A.; Aly, A.S. Synthesis and Preliminary Antimicrobial Activity of New Pyrimido[4,5b]quinolone, and Pyrido[2,3-d]pyrimidine. Phosphorus Sulfur Silicon Relat. Elem. 2008, 183, 2119-2138. [CrossRef]

38. Ashok, D.; Ganesh, A.; Ravi, S.; Lakshmi, V.B.; Ramesh, B. Solvent free microwave assisted synthesis of $(E)-1-\{3-[2-(9-E t h y l-9 H-$ carbazol-3-yl)vinyl] benzofuran-2-yl\}-2,2-dimethylpropan-1-ones and their antimicrobial activity. Russ. J. Gen. Chem. 2014, 84, 2211-2217. [CrossRef]

39. Hafez, H.N.; Al- Hussain, S.; El-Gazzar, A.B.A. One-Pot Microwave Synthesisof Pyrimido[4,5-b]quinoline and its C- and SGlycosides with Anti-Inflammatory and Anticancer Activities. Croat. Chem. Acta 2016, 89, 285-296. [CrossRef]

40. Saito, K.; Kambe, S.; Nakano, Y. Synthetic studies using $\alpha, \beta$-unsaturated nitriles: A convenient preparation of 1,3-benzothiazole derivatives. Synthesis 1983, 3, 210-212. [CrossRef]

41. Nijs, A.; Cartuyvels, R.; Mewis, A.; Peeters, V.; Rummens, J.L.; Magerman, K. Comparison and Evaluation of Osiris and Sirscan 2000 Antimicrobial Susceptibility Systems in the Clinical Microbiology Laboratory. J. Clin. Microbiol. 2003, 41, 3627-3630. [CrossRef] [PubMed]

42. Naeimi, H.; Nazifi, Z.S.; Amininezhad, S.M.; Amouheidari, M. Synthesis, characterization and in vitro antimicrobial activity of some new Schiff bases and their complexes. J. Antibiot. 2013, 66, 687-689. [CrossRef] [PubMed]

43. Dorman, H.J.D.; Hiltunen, R. Fe(III) reductive and free radical-scavenging properties of summer savory (Satureja hortensis L.) extract and subfractions. Food Chem. 2004, 88, 193-199. [CrossRef]

44. Aeschlach, R.; Loliger, J.; Scott, B.C.; Murcia, A.; Butler, J.; Halliwell, B.; Aruoma, O. Antioxidant actions of thymol, carvacrol, 6-gingerol, zingerone and hydroxytyrosol. Food Chem. Toxicol. 1994, 32, 31-36. [CrossRef] 